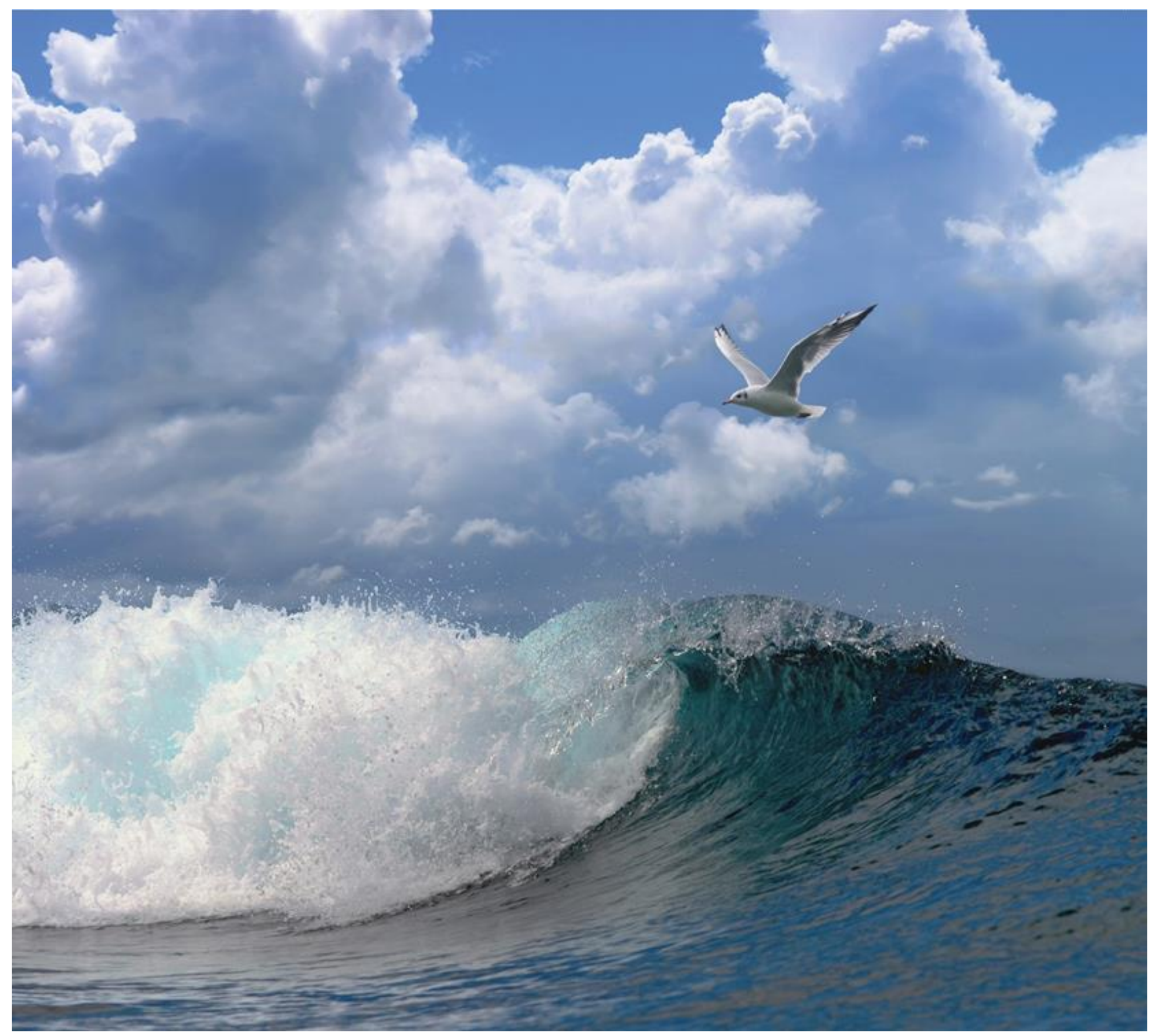

\title{
Increasing the survival of discards in North Sea pulse-trawl fisheries
}




\section{Increasing the survival of discards in North Sea pulse-trawl fisheries}

Author(s): $\quad$ Pieke Molenaar and Edward Schram

Publication date: 14 May 2018 
Pieke Molenaar and Edward Schram,2018. Increasing the survival of discards in North Sea pulse trawl fisheries. Wageningen, Wageningen Marine Research (University \& Research centre), Wageningen Marine Research report C038/18. 39 pp.

Client: $\quad$ Visned

Attn.: Wouter van Broekhoven

Postbus 59

8320 AB Urk

The Netherlands

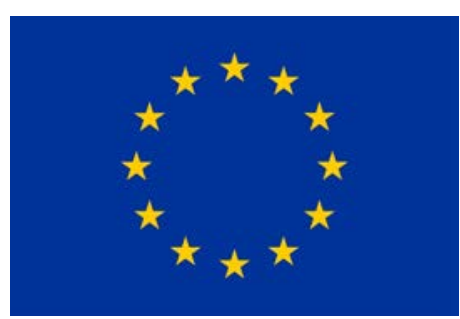

European Union, European Maritime and Fisheries Fund (EMFF)

This report can be downloaded for free from https://doi.org/10.18174/449808

Wageningen Marine Research provides no printed copies of reports

Wageningen Marine Research is ISO 9001:2008 certified.

Photo cover: Edward Schram

\section{(c) 2018 Wageningen Marine Research Wageningen UR}

Wageningen Marine Research institute of Stichting Wageningen Research is registered in the Dutch traderecord nr. 09098104, BTW nr. NL 806511618
The Management of Wageningen Marine Research is not responsible for resulting damage, as well as for damage resulting from the application of results or research obtained by Wageningen Marine Research, its clients or any claims related to the application of information found within its research. This report has been made on the request of the client and is wholly the client's property. This report may not be reproduced and/or published partially or in its entirety without the express written consent of the client. 


\section{Contents}

Preface

Summary

1 Introduction

$2.1 \quad$ Experimental design $\quad 8$

2.1.1 Ethics statement $\quad 8$

2.1.2 Outline of the experiments $\quad 8$

2.1.3 Sea trips $1: 8$

2.1.4 Treatment 1: Water filled hopper 9

2.1.5 Treatment 2: Short hauls 11

2.1.6 Treatment 3: Knotless cod-end 11

$\begin{array}{lll}2.1 .7 & \text { Control-fish } & 12\end{array}$

$\begin{array}{lll}2.2 & \text { Assessment of fish condition and monitoring of survival } & 13\end{array}$

$\begin{array}{lll}2.3 & \text { Experimental facilities } & 13\end{array}$

$\begin{array}{lll}2.4 & \text { Data analysis } & 14\end{array}$

3 Results $r$

$\begin{array}{lll}3.1 & \text { Survival of control-fish } & 16\end{array}$

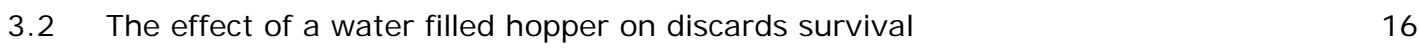

3.2.1 Main effect of a water filled hopper 16

3.2.2 Effects of sea trips and vessels on the effect of the water filled hopper $\quad 17$

$\begin{array}{ll}\text { 3.2.3 Effect of a water filled hopper on fish condition } & 18\end{array}$

3.2.4 Interactive effects of fish condition and a water filled hopper on discards survival probability 18

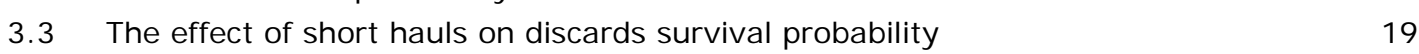

$\begin{array}{ll}\text { 3.3.1 Main effects of short hauls } & 19\end{array}$

$\begin{array}{ll}\text { 3.3.2 Effect of short hauls on fish condition } & 20\end{array}$

3.3.3 Interactive effects of fish condition and short hauls on discards survival $\begin{array}{ll}\text { probability } & 20\end{array}$

3.4 Effect of a knotless cod-end on discards survival probability 21

4 Discussion $\quad 22$

$\begin{array}{lll}4.1 & \text { General } & 22\end{array}$

$\begin{array}{ll}4.2 & \text { Water filled hopper } \\ 4.3 & 22\end{array}$

$\begin{array}{lll}4.3 & \text { Short hauls and knotless cod-end } & 24\end{array}$

$5 \quad$ Conclusions and recommendations $\quad 25$

$\begin{array}{llr}6 & \text { Acknowledgements } & 26\end{array}$

$\begin{array}{llr}7 & \text { Quality Assurance } & 27\end{array}$

$\begin{array}{lr}\text { References } & 28\end{array}$

$\begin{array}{lr}\text { J ustification } & 29\end{array}$

$\begin{array}{lr}\text { Annex 1: Survival per trip } & \mathbf{3 0}\end{array}$ 


\section{Preface}

The project 'Survival of flatfish and ray discards' investigates four topics related to flatfish and ray discards survival in the $80 \mathrm{~mm}$ pulse-trawl fisheries in the North Sea: 1. Discards survival of undersized plaice, sole, turbot, brill, thornback ray and spotted ray in conventional pulse-trawl fisheries, 2. Measures to increase discards survival, 3. Factors affecting discards survival and 4 . The use of vitality index scores as a proxy for discards survival.

Each topic will be reported separately and the current report is the second in the series of four reports delivered by the project.

All research data for this project were collected during nine sea trips with three commercial pulsetrawlers. Utilization of methods and research data partly overlaps among the four topics. In addition, each report can be read independently from the other reports in the series. Consequently the description of methods and reporting of data partly overlaps in the four reports.

In a later stage, parts of the results presented in these four reports will be submitted for publication in peer-reviewed scientific journals. These four reports should be considered as pre-publications of final results.

The project was commissioned by VISNED and received financial support from the European Maritime and Fisheries Fund (EMFF) of the European Union.

May, 2018. 


\section{Summary}

Measures to increase discard survival in the $80 \mathrm{~mm}$ pulse-trawl fisheries were assessed under commercial fishing conditions using plaice (Pleuronectes platessa) as model species. Measures tested were a water filled hopper ( 8 sea trips), short hauls (90 instead of $120 \mathrm{~min}, 4$ sea trips) and a knotless cod-end ( 1 sea trip) with undersized plaice. In total nine sea trips were performed with three different commercial pulse-trawlers. Sea trips were spread over the year to account for potential seasonal variation in discards survival. Additional trials with a knotless cod-end (one sea trip) and water filled hopper (2 sea trips) were performed with undersized sole. Effects were assessed by comparing survival to conventional conditions (dry hopper, conventional haul duration, conventional cod-end) for which data were collected from the same or subsequent hauls.

All test-fish were randomly collected from the end of the sorting belt at both the start and end of the catch-sorting process from multiple hauls per sea trip. Reflex impairment and damages were assessed for all test-fish and summarized in a vitality index score. Test-fish were housed on-board in custombuilt monitoring units containing 16 (24L) tanks with five fish each tank. Tank water was continuously renewed with sea water at a rate of at least two tank volumes per hour to maintain proper water quality. Survival was monitored and dead fish were removed upon detection. Upon arrival in the vessel's home port, monitoring units were road transported to the laboratory to continue survival monitoring for two more weeks. Total monitoring period ranged from 15 to 18 days among test-fish depending on the day of collection at sea. In the laboratory tank bottoms were covered with coarse sand and fish were fed natural food. In total 558 plaice from conventional fisheries (ca. 60 per sea trip) were collected, 478 plaice for the water filled hopper treatment (ca. 60 per sea trip), 200 plaice from short hauls (ca. 40 and 60 each in two sea trips) and 60 plaice from the knotless cod-end.

Control-fish of the same species, in good condition and not exposed to the fishing gear were deployed during all sea trips (circa 30 control plaice and circa 15 control sole per sea trip). Control-fish were handled and tagged as test-fish to separate fisheries related mortality from mortality caused by the experimental procedures.

Discards survival probabilities and their 95\% confidence intervals $(\mathrm{Cl})$ were estimated from counts of surviving fish at the end of the monitoring period. For all sea trips combined, no significant effect of a water filled hopper on plaice discards survival probability could be detected with $16 \%(95 \% \mathrm{Cl} 12$ $19 \%)$ for the conventional dry hopper and $20 \%(95 \% \mathrm{Cl} 15-25 \%)$ for the water filled hopper. Within the individual sea trips, a significantly higher survival probability for plaice discards from the water filled hopper was found for three sea trips. In three other sea trips a lower survival of plaice discards was detected for the water filled hopper, although the difference with the dry hopper was not significant. Given this observation, it cannot be entirely excluded that the water filled hopper can also have a negative effect on discards survival. For sole discards the effect of a water filled hopper was tested during two sea trips only, yielding a higher survival probability of sole discards for the water filled hopper $(14 \%, 95 \% \mathrm{Cl} 10-21 \%)$ compared to the dry hopper $(5 \%, 95 \% \mathrm{Cl} 2-10 \%)$.

Deployment of a water filled hopper results in a shift towards a better condition of the discarded fish. Despite this effect, the total proportion of fish in good condition within catches remained small. We therefore recommend to prioritize measures aimed at improving fish condition in the trawl to increase discards survival chances.

For all sea trips combined, no effect of short ( 90 instead of $120 \mathrm{~min}$ ) hauls on discards survival probability could be detected: survival probabilities for plaice discards were equal at $11 \%(95 \% \mathrm{Cl} 8$ $15 \%$ ) for both short and conventional hauls. No effect of a knotless cod-end on plaice and sole discards survival probability could be detected.

In conclusion, deployment of a water filled hopper does not result in higher survival probability for plaice discards than a conventional dry hopper in year-round pulse-trawl fisheries. However, it is clear 
that for individual trips the deployment of a water filled hopper can result in an increase of survival chances of discarded plaice, but as it seems only under certain specific, yet to be established, conditions. In addition, it cannot be excluded at this point that under certain conditions a water filled hopper may have a negative effect on discards survival. For sole a positive effect of the water filled hopper on discards survival was detected. However, since sole was tested during two sea trips only, the current findings may not be representative for year-round fisheries and the positive effect may be specific for the conditions that prevailed during the two trips. Survival probability of plaice and sole discards cannot be increased by reducing haul duration from 120 to 90 min or using a knotless codend. 


\section{$1 \quad$ Introduction}

Demersal pulse-trawl fisheries in the North Sea is a mixed fishery that mainly targets Dover sole (Solea solea) and plaice (Pleuronectes platessa). Undersized and over quota fishes and species with no market value are discarded. By 2019 this practise of discarding will be restricted for all quota regulated species by the implementation of a landing obligation under the Common Fisheries Policy (European Union, 2013). As a result of this legislation fishermen will be forced to land all undersized, damaged and marketable fish of species under quota management, also referred to as a landing obligation (LO). However, this landing obligation allows exemptions for species which according to the best available scientific advice have a high survival rate when released into the sea, taking into account gear characteristics, fishing practices and the ecosystem.

Previous work on the survival of discards from pulse-trawl fisheries resulted in survival probability estimates of $15 \%(95 \% \mathrm{Cl}: 11-19 \%)$ for plaice and $29 \%(95 \% \mathrm{Cl}: 24-35 \%)$ for sole (Van der Reijden et al., 2017). More recently, we reported a very similar discards survival probability estimate of $14 \%$ (95\% Cl 11-18\%) for plaice (Schram and Molenaar, 2018). For undersized sole we reported a slightly lower discards survival than Van der Reijden et al. (2017) of $19 \%$ (95\% Cl $13-28 \%$ ).

Several measures aimed at increasing the post-capture survival of fish when released into the sea have been explored with promising results. Reducing haul duration from 100-130 min to 60-70 min was found to promote the survival of plaice discards but not sole discards (Van der Reijden et al., 2017). Haul duration reduction is preferably limited as for its significant operational impact on-board fishing vessels and effect on total fishing time per trip. Preliminary work on the effect of a water filled hopper instead of the common practise of discharging catches from the cod-end into a dry hopper suggested an increase of the survival of plaice discards (Van Marlen et al., 2016), although data were insufficient to draw final conclusions.

This study therefore assessed the effect of a reduction of haul duration to 90 min and a water filled hopper on survival of discards in the $80 \mathrm{~mm}$ pulse-trawl fisheries. In addition, the effect of a knotless cod-end was tested. These measures (treatments) were implemented at three commercial pulsetrawlers during nine sea trips. Their effects were assessed by comparing survival of undersized plaice and sole discards collected from modified and conventional fisheries. 


\section{Materials and Methods}

\section{$2.1 \quad$ Experimental design}

\subsubsection{Ethics statement}

The treatment of the fish was in accordance with the Dutch animal experimentation act, as approved by ethical committees (Experiment 2017 D0012.002)

\subsubsection{Outline of the experiments}

Measures aimed at increasing discards survival were assessed by comparing discards survival between modified (one of the measures implemented) and conventional fisheries and catch processing practices. Fish were collected during nine sea trips with three commercial pulse-trawlers and three trips per pulse-trawler. Within each sea trip, fish were collected from multiple hauls to account potential for variation in discards survival among hauls. The typical number of hauls was 40 to 50 per sea trip. Survival monitoring started during the sea trip and was continued on land for 14 days after the fish had been transferred to the laboratory. Total survival monitoring time ranged from 15 to 18 days after collecting test-fish at sea. Measures tested for their effects on discards survival included the treatments; short hauls (S), a water filled hopper (W) and a knotless cod end (K). An overview of treatments per sea trip and the number of test-fish collected is provided in Table 1.

Table 1 Overview of sea trips and fish sampling: total number of test-fish collected and control-fish deployed per species and sea trip and treatment and the survival of the control-fish

\begin{tabular}{|c|c|c|c|c|c|c|c|c|c|c|c|c|c|}
\hline \multirow[t]{2}{*}{ Trip } & \multirow[t]{2}{*}{ Vessel } & \multirow{2}{*}{$\begin{array}{l}\text { Treatments } \\
\text { tested }(\mathbf{R}, \mathbf{C} \text {, } \\
\mathbf{W}, \mathbf{S}, \mathrm{K})^{*}\end{array}$} & \multicolumn{5}{|c|}{$\begin{array}{l}\text { \# Plaice collected per } \\
\text { treatment }\end{array}$} & \multicolumn{4}{|c|}{$\begin{array}{c}\text { \# Sole collected per } \\
\text { treatment }\end{array}$} & \multicolumn{2}{|c|}{ Survival of control-fish } \\
\hline & & & $\mathbf{R}$ & c & w & $\mathrm{s}$ & k & $\mathrm{R}$ & c & w & $\mathrm{K}$ & Plaice & Sole \\
\hline 1 & 1 & $R, C, W, S$ & 35 & 60 & 60 & 40 & - & - & - & - & - & $100 \%$ & - \\
\hline 2 & 2 & $\mathrm{R}, \mathrm{C}, \mathrm{W}, \mathrm{S}$ & 30 & 60 & 59 & 60 & - & - & - & - & - & $97 \%$ & - \\
\hline 3 & 3 & $\mathrm{R}, \mathrm{C}, \mathrm{W}, \mathrm{S}$ & 30 & 60 & 60 & 60 & - & - & - & - & - & $100 \%$ & - \\
\hline 4 & 3 & $R, C, W, S$ & 30 & 59 & 59 & 40 & - & - & - & - & - & $90 \%$ & - \\
\hline 5 & 1 & $\mathrm{R}, \mathrm{C}, \mathrm{K}$ & 33 & 80 & - & - & 60 & 10 & 33 & - & 31 & $30 \%$ & $90 \%$ \\
\hline 6 & 3 & $\mathrm{R}, \mathrm{C}, \mathrm{W}$ & 30 & 60 & 60 & - & - & 15 & 30 & 30 & - & $100 \%$ & $100 \%$ \\
\hline 7 & 2 & $\mathrm{R}, \mathrm{C}, \mathrm{W}$ & 30 & 60 & 60 & - & - & 15 & 30 & 30 & - & $72 \%$ & $100 \%$ \\
\hline 8 & 1 & $\mathrm{R}, \mathrm{C}, \mathrm{W}$ & 30 & 58 & 60 & - & - & - & - & - & - & $72 \%$ & - \\
\hline 9 & 2 & $R, C, W$ & 29 & 59 & 60 & - & - & - & - & - & - & $93 \%$ & - \\
\hline \multicolumn{3}{|c|}{ Total/ overall } & 277 & 576 & 478 & 200 & 60 & 40 & 93 & 60 & 31 & $84 \%$ & $97 \%$ \\
\hline
\end{tabular}

* $\mathrm{R}=$ controls, $\mathrm{C}=$ Conventional, $\mathrm{W}=$ Water filled hopper, $\mathrm{S}=$ Short 90 minute haul, $\mathrm{K}=$ knotless cod-end.

\subsubsection{Sea trips}

All nine sea trips were conducted in the Southern North Sea according to the regular commercial practices of the pulse-trawlers. Sea trips typically started on Mondays around 0:00 and ended on Fridays around 4:00. Sea trips were spread out over the year (Table 2) to account for the potential effect of varying fishing conditions throughout the year on discards survival (Van der Reijden et al., 2017). For each haul during a sea trip the operational and environmental conditions were recorded by the skipper. Locations and conditions during the sea trips are presented in Table 2 and Figure 1 . Vessel and gear specifics are presented in Table 3. 
Table 2 Conditions during the sea trips

\begin{tabular}{|c|c|c|c|c|c|c|c|c|c|c|c|}
\hline Trip & Vessel & Year & Month & Week & \multicolumn{2}{|c|}{$\begin{array}{c}\text { Temperature } \\
\left({ }^{\circ} \mathrm{C}\right)\end{array}$} & $\begin{array}{c}\text { Wind } \\
\text { Speed } \\
(\mathrm{Bft})\end{array}$ & $\begin{array}{c}\text { Wave } \\
\text { height } \\
(\mathrm{m})\end{array}$ & $\begin{array}{c}\text { Catch } \\
\text { processing } \\
(\mathrm{min})\end{array}$ & $\begin{array}{c}\text { Haul } \\
\text { duration } \\
(\mathrm{min})\end{array}$ & $\begin{array}{c}\text { Fishing } \\
\text { depth } \\
(\mathrm{m})\end{array}$ \\
\hline 1 & 1 & 2017 & May & 18 & - & $9-12$ & $2-5$ & $0.5-2.0$ & 25 & $85-135$ & $26-28$ \\
\hline 2 & 2 & 2017 & May & 21 & $14-18$ & $12-13$ & $1-4$ & $0.2-0.5$ & 24 & $90-120$ & $39-50$ \\
\hline 3 & 3 & 2017 & June & 24 & $15-20$ & $14-15$ & $1-2$ & $0.1-0.5$ & 18 & $90-125$ & $22-25$ \\
\hline 4 & 3 & 2017 & July & 28 & $15-21$ & $16-17$ & $1-6$ & $0.2-1.0$ & 18 & $90-120$ & $28-40$ \\
\hline 5 & 1 & 2017 & Sept & 36 & $15-18$ & 18 & $4-5$ & $0.5-1.0$ & 21 & $120-130$ & $26-37$ \\
\hline 6 & 3 & 2017 & Oct & 44 & $13-15$ & $13-15$ & $3-4$ & $1.0-1.2$ & 20 & $120-130$ & $30-31$ \\
\hline 7 & 2 & 2017 & Dec & 49 & $6-9$ & $11-12$ & $3-5$ & $1.0-2.0$ & 33 & 120 & $37-50$ \\
\hline 8 & 1 & 2018 & Jan & 4 & 8 & $6-7$ & $5-6$ & $1.0-1.7$ & 33 & 120 & $28-35$ \\
\hline 9 & 2 & 2018 & Feb & 8 & 6 & $7-8$ & $3-4$ & $0.5-1.0$ & 24 & $110-120$ & $40-45$ \\
\hline
\end{tabular}

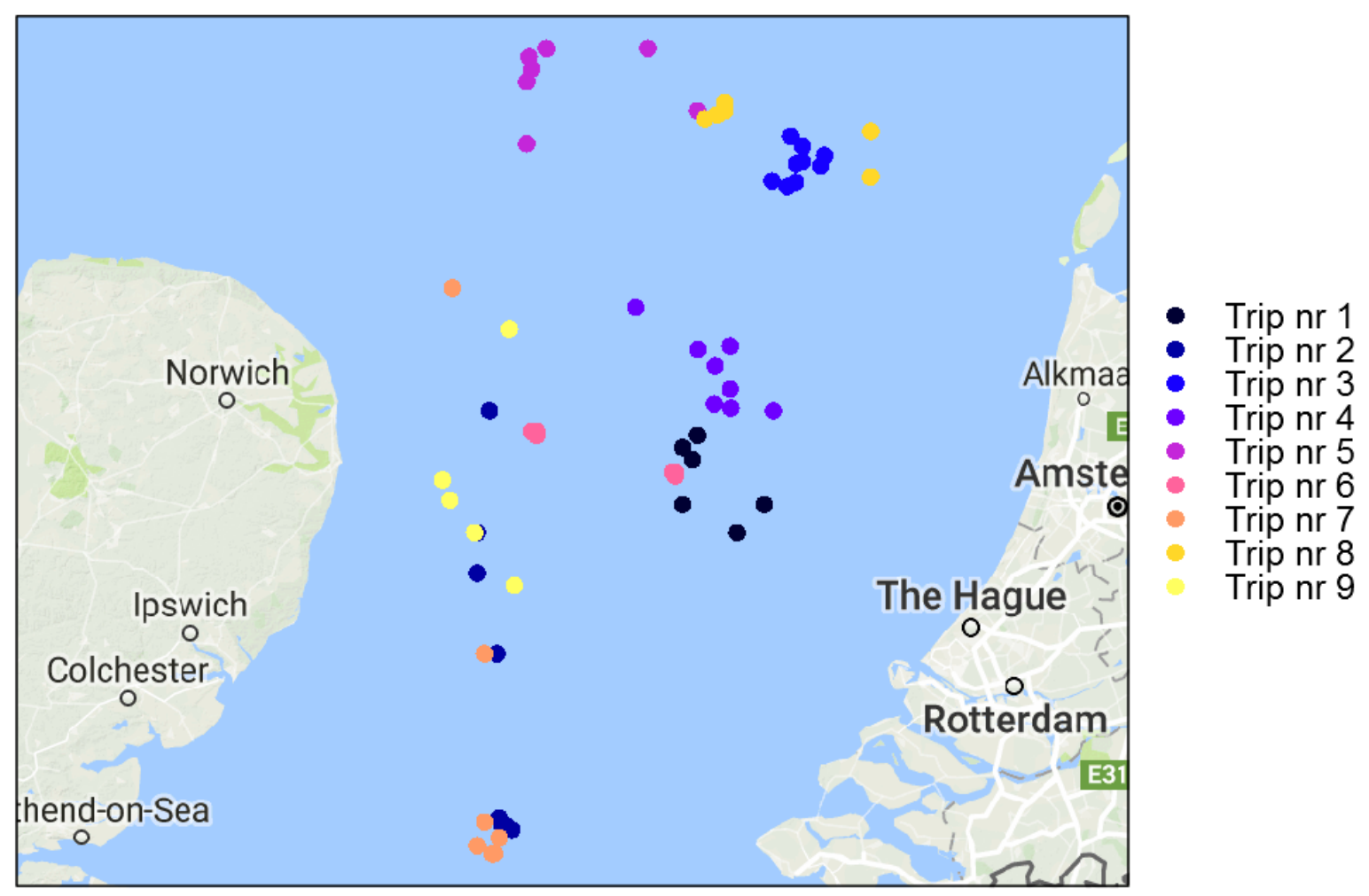

Figure 1. Fishing locations trials per sea trip

\subsubsection{Treatment 1: Water filled hopper}

The effect of a water filled hopper on discards survival was tested on model species plaice during eight sea trips (all except trip 5, Table 1) to cover fishing conditions as they prevail year-round. Test with sole were conducted during two sea trips(trips 6 and 7, Table 1) to gain some insight in the effect of the water filled hopper on other species than the model species.

Several modifications were applied to one of the two hoppers on each participating vessel to be able to operate it as a water filled hopper. The 1.5 to $2 \mathrm{~m}$ tall water canon/hose that is used to flush catch from the hopper to the conveyer belt was replaced by one or multiple water inlets located 10-20 cm 
above the hopper bottom to reduce mechanical water pressure on the catch during processing. Additional to the water hose modifications, three step cascade flow control devices were applied in the hopper's opening to the conveyor belt to maintain water levels in the hopper and enable stepwise catch processing. Before hauling the cod-end on-board, the modified hopper was filled with ample seawater to maintain a water level of 40 to $50 \mathrm{~cm}$. As a result the catch was discharged in water instead of on the metal surface of the hopper bottom. After discharging the catch, the hopper was continuously supplied with seawater to maintain water and oxygen levels in the modified hoppers. Stepwise catch processing was applied for the modified hoppers to prevent catch piling up on the conveyor belt and maximise time spent in the water filled hopper. In addition, the stepwise processing results in most of the fish being processed while the majority of benthic animals and debris remain in the water filled hopper and are processed last only after removing the third cascade.

The water filled hopper treatment (W) was installed at one side of each trawler. The other hopper was not filled with water according to conventional practices and served as control treatment (C) (not to be confused with control-fish, see 2.2.7). For each haul the starboard and port side catches were kept and processed separately and thus appeared as two separate batches on the sorting belt to allow for test-fish collection for both treatments. All test-fish were randomly collected from the end of the sorting belt (Figure 1) from six (plaice) or two (sole) hauls per sea trip to account for potential variation in fishing conditions and discards survival among hauls. To obtain representative samples from hauls, the potential effects of processing time on discards survival (Benoit et al., 2013) were accounted for by collecting test-fish in equal numbers at both the start and the end of the catchsorting process of each haul. The processing sequence of the two hoppers was alternated between hauls to obtain an equal average catch-processing time across the collected test-fish for both treatments. For each sampled haul, the time the catches were discharged in the hoppers as well as the time of collection of individual fish were recorded to determine catch-processing time per individual fish.

Plaice were collected during eight sea trips from six hauls per trip. Each haul ten fish per treatment were collected, five at the start and five at the end of the catch-sorting process for each hopper. This resulted in a total of 60 plaice per treatment for each sea trip and 478 plaice per treatment for the entire experiment.

Sole were collected during two sea trips from two hauls per trip. Each haul 15 fish per treatment were collected, resulting in a total of 30 sole per treatment for each sea trip and 60 sole per treatment for the entire experiment. 


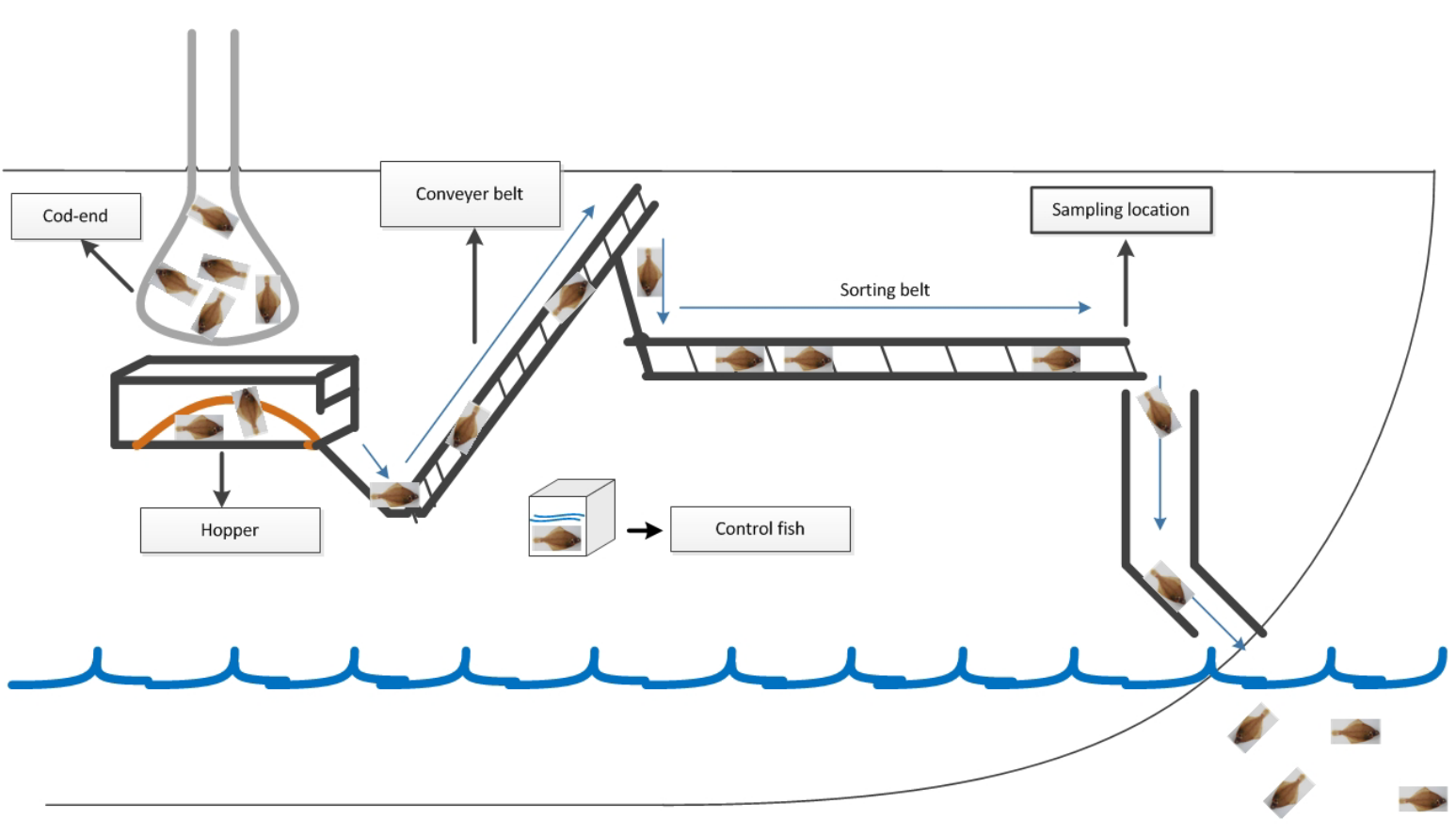

Figure 1. Schematic drawing of semi-automatic catch processing line on board of a pulse trawler. All fish collected from the catch for the survival experiment are collected at the location marked with 'sample location'.

\subsubsection{Treatment 2: Short hauls}

The effect of short hauls (S, circa $90 \mathrm{~min}$.) on discards survival was tested on plaice during the first four sea trips (Table 1, page 8). Test-fish were collected at the start and the end of the catch-sorting process at the end of the sorting belt (Figure 1). Plaice from hauls of conventional duration (circa 120 min) were collected the haul before or after the short haul during the same sea trip served as conventional reference treatment. These controls for short hauls are the same test-fish (C) as collected as conventional 'controls' for the water filled hopper treatment (see 2.2.4, Table 1). During trips 1 and 4, 40 undersized plaice were sampled from two short hauls (20 per haul). During trips 2 and 3, 60 undersized plaice were sampled from three short hauls ( 20 per haul), resulting in a total of 200 test-fish for the short haul treatment in the entire experiment.

\subsubsection{Treatment 3: Knotless cod-end}

The effect of a knotless cod-end on discards survival was tested on plaice and sole during one sea trip. Based on this single test it seemed clear that the knotless cod-end was not a breakthrough measure with a large positive effect on discards survival. Testing of the knotless cod-end was consequently not continued after one sea trip. The knotless cod-end $(K)$ was connected to the starboard trawl and tested during sea trip 5 (Table 1, page 8). The conventional cod-end at the port side served as conventional 'control' treatment (C). The knotless cod-end was deployed for in total six hauls. During knotless cod-end trials the hoppers were used according to regular practice; not filled with water. For each haul the starboard and port side catches were kept, processed and sampled separately from the end of the sorting belt (Figure 1). The order in which the catches per treatment were processed and sampled was alternated between each sampled haul to obtain an equal number of 'first processed' catches for both treatments. From each haul 10 undersized plaice per treatment ( $C$ and $K$ ) were randomly collected, five at the start and five at the end of the catch-sorting process, resulting in a total of 60 plaice per treatment. Sole were only sampled from two hauls with 14 and 16 fish collected per treatment and haul. 
Table 3 Vessel and gear specifics

\begin{tabular}{|c|c|c|c|c|}
\hline \multicolumn{2}{|l|}{ Specifics } & \multirow{2}{*}{\begin{tabular}{|l|} 
Vessel 1 \\
1471
\end{tabular}} & \multirow{2}{*}{$\frac{\text { Vessel } 2}{1430}$} & \multirow{2}{*}{$\frac{\text { Vessel } 3}{1470}$} \\
\hline & $\begin{array}{l}\text { Engine power } \\
(\mathrm{Kw})\end{array}$ & & & \\
\hline & Gear & Sumwing pulse & Sumwing pulse & Sumwing pulse \\
\hline & Number of gears & 2 & 2 & 2 \\
\hline & $\begin{array}{l}\text { Fishing speed } \\
(\mathrm{kn})\end{array}$ & 4.8 & 4.8 & 4.9 \\
\hline \multirow[t]{3}{*}{ Beam (wing) } & Width $(\mathrm{m})$ & 12 & 12 & 12 \\
\hline & Length (m) & 1.1 & 1.1 & 1.1 \\
\hline & Total weight $(\mathrm{kg})$ & 2600 & 2740 & 2300 \\
\hline \multirow[t]{4}{*}{ False ground rope } & Type & Rubber discs & Rubber discs & Rubber discs \\
\hline & Length (m) & 11.7 & 11 & 11.8 \\
\hline & Diameter (mm) & 220 & 120 & 120 \\
\hline & Total weight $(\mathrm{kg})$ & 110 & 140 & 80 \\
\hline \multirow[t]{5}{*}{ Electrodes } & Number & 22 & 24 & 26 \\
\hline & Type & HFK & HFK & HFK \\
\hline & Total length $(\mathrm{m})$ & \begin{tabular}{|l|}
7.5 \\
\end{tabular} & 7.2 & 7.4 \\
\hline & $\begin{array}{l}\text { Distance between } \\
\text { electrodes }(\mathrm{cm})\end{array}$ & 40.0 & 42.5 & 45.0 \\
\hline & $\begin{array}{l}\text { Length electrodes } \\
\text { on seabed (pulse } \\
\text { field) }(\mathrm{m})\end{array}$ & 3.0 & 3.2 & 4.4 \\
\hline \multirow[t]{4}{*}{ Conductor elements } & Number & 11 & 10 & 12 \\
\hline & Diameter (mm) & 35 & 28 & 33 \\
\hline & Length ( $\mathrm{mm})$ & 130 & 130 & 134 \\
\hline & $\begin{array}{l}\text { Distance between } \\
\text { elements }(\mathrm{mm})\end{array}$ & 220 & 210 & 200 \\
\hline \multirow[t]{5}{*}{ Pulse } & Power $(\mathrm{kW} / \mathrm{m})$ & 6.0 & 5.3 & 7.3 \\
\hline & Width $(\mu s)$ & 340 & 390 & 330 \\
\hline & Frequency $(\mathrm{Hz})$ & 60 & 45 & 60 \\
\hline & $\begin{array}{l}\text { Peak voltage over } \\
\text { electrode }(\mathrm{V})\end{array}$ & 60 & 60 & 60 \\
\hline & $\begin{array}{l}\text { Maximum } \\
\text { exposure to pulse } \\
\text { field (s) }\end{array}$ & 1.2 & 1.3 & 1.7 \\
\hline \multirow[t]{4}{*}{ Trawl } & Total length (m) & 34 & 30 & 34 \\
\hline & $\begin{array}{l}\text { Mesh size cod-end } \\
(\mathrm{mm})\end{array}$ & 80 & 80 & 80 \\
\hline & Twine cod-end & Double knotted & Double knotted & Double knotted \\
\hline & $\begin{array}{l}\text { Twine thickness } \\
(\mathrm{mm})\end{array}$ & 4 & 3 & 3 \\
\hline
\end{tabular}

\subsubsection{Control-fish}

In each of the nine sea trips, control plaice and sole ( $R$ in Table 1, page 8) were deployed to separate potential effects of the experimental procedures on mortality from fisheries induced mortality. During each of the nine sea trips, control-fish were transported from the research facilities to the vessel and taken on-board of the pulse-trawler. At the vessel control-fish were stored on deck in aerated 600L tanks with regularly renewed surface seawater. Only fish in visually observed good condition, well fed and without visible injuries, were selected for use as control-fish. Control-fish were exposed to the exact same experimental procedures as the test-fish, including vitality assessment, tagging and housing in the monitoring units throughout the experiments. The number of control-fish deployed was approximately $30 \%$ of the number of test-fish per species (Table 1 ) 
Control-fish were obtained by commercial shrimp and pulse beam trawlers $(<221 \mathrm{~kW})$ which had been requested to collect least damaged and undersized fish from short hauls. Control-fish were also collected during the sea trips with the pulse-trawlers for use in subsequent sea trips. In both cases collected fish were stored on-board in $600 \mathrm{~L}$ containers filled with surface seawater which was aerated and regularly exchanged to maintain proper water quality. Prior to their use as control-fish were stored in tanks placed in a climate controlled room for at least three weeks. During this period, fisheries induced mortality levelled out while surviving fish could recover from injuries and regain good condition. Tanks with candidate control-fish were inspected daily for mortalities which were removed upon detection. During storage, fish were fed daily with live polychaete worms (Nereis spp) and dead, uncooked brown shrimps (Crangon crangon) to visually observed satiation.

\subsection{Assessment of fish condition and monitoring of survival}

After collection from the sorting belt, test-fish were temporarily stored in $105 \mathrm{~L}$ holding containers filled with seawater. The seawater in the holding containers was regularly renewed to maintain sufficient dissolved oxygen levels during storage. Upon completion of fish collection, fish were sequentially taken from the holding containers to measure total length (TL: in cm below) and for vitality assessment and tagging. Fish were taken randomly from the holding containers in case more than the required number of fish had been collected. Vitality status of each individual fish was assessed by scoring vitality index class, external damage and reflex impairment as described by Van der Reijden et al. (2017) and summarized in Table 4. For thornback and spotted ray the protocols for external damage and reflex impairment scores in flatfish by Van der Reijden et al. (2017) were adapted (Table 4, page 15).

Individual fish were tagged with Trovan Unique glass transponders (type ID100) to allow for identification of individuals throughout the experiments. Transponders were injected subcutaneously just behind the head using the IIDIO0E injector. Upon completion of the vitality assessment and tagging, live fish were placed in $24 \mathrm{~L}$ tanks (see Experimental facilities) with a maximum of five fish per tank. Fish that were dead (defined as the absence of Head-complex, Table 4) at the moment of vitality assessment were recorded as dead at time zero. Dead fish were stored on ice and not replaced by live individuals.

Monitoring of survival and experimental conditions started after the first fish had been placed in the monitoring units. All tanks containing fish were inspected every 12 hours on-board and every 24 hours after transfer to the laboratory. Tanks were inspected for mortalities through or by lifting the transparent lid of the tanks by visual observation of fish movement. In case any mortalities were suspected to be present, these individuals were gently touched with a blunt plastic probe to provoke a behavioural response. Fish that showed no response were manually removed from the tank and dead was confirmed by visual observation of a 15 seconds absence of gill plate/spiracle movement in water and the 'head complex' reflex (Table 4). Lethargic fish were not removed. Dissolved oxygen concentration and saturation and water temperature were measured (Hach Lange Multimeter). Water flows to the tanks were increased if oxygen saturation was below $80 \%$.

\subsection{Experimental facilities}

All test-fish collected during sea trips and control-fish were housed in four custom-built monitoring units installed on-board of the vessels. Each unit consisted of a stainless steel framework which holds $1624 \mathrm{~L}$ tanks $(60 \mathrm{~cm} \mathrm{~L} \times 40 \mathrm{~cm} \mathrm{~W} \times 12 \mathrm{~cm} \mathrm{H}$ ), resulting in a total capacity of 64 tanks on a vessel. Each tank was equipped with an individual water supply. A central pump installed on the vessel continuously supplied surface seawater to the tanks. The water intake of this pump was approximately 2 meters below sea surface. Water flow rates to the tanks were installed at approximately two tank volumes per hour (1-1.5 $\mathrm{L}^{-1} \mathrm{~min}$ ) to maintain proper water quality. Tanks were covered with transparent lids to limit water losses by sloshing while allowing for visual inspection of the fish. Upon return of the vessels in their home ports, the entire units were off-loaded and transported to the 
laboratory by road in a temperature controlled truck. Transport time ranged from one to three hours depending on the home port of the vessel. During transport each unit was placed inside a pumping tank partly filled with seawater and equipped with a submerged pump to supply water to each fish tank in the unit. Fish tanks discharged their effluents in the pumping tank, allowing for recirculation and aeration of the water. Upon arrival at the laboratory the fish tanks were manually stacked in racks. All tanks were connected to a single water recirculation system consisting of a $440 \mathrm{~L}$ pumping tank and a $330 \mathrm{~L}$ trickling filter. Total system volume was approximately $3.2 \mathrm{~m}^{3}$ and continuously renewed with filtered water from the Eastern Scheldt at a rate of $8.6 \mathrm{~m}^{3} / \mathrm{d}$. All tanks were placed in a temperature controlled room with its temperature set at the actual North Sea surface water temperature at the time of test-fish collection. In the laboratory, all tanks were supplied with coarse sand as bottom substrate and the fish were fed daily to visually observed satiation with polychaete worms (Nereis spp) and uncooked brown shrimps (Crangon crangon). On-board, bottom substrate was not applied as in combination with the inevitable rocking of the vessels, sand would probably result in injuries through abrasion of the fish. Fish were not fed on-board as in our experience from previous discards survival studies they do not restart feeding until several days after catching while uneaten feed in the tanks would compromise water quality.

\subsection{Data analysis}

Survival, fish condition and sampling related time data were all collected the level of the individual fish. Fish were either dead or alive at the end of the survival monitoring period.

For each fish that died during the course of survival monitoring, the survival time was recorded as the time $(h)$ since collection from a catches. Survival curves presenting the development over time of survival within a group, were estimated using the non-parametric Kaplan-Meier estimator (Kaplan and Meier, 2012).

The effect of a water filled hopper on discards survival was tested by comparing estimates for discards survival probabilities for the water filled and dry hopper for all sea trips combined and the individual sea trip separately. Survival probabilities per treatment were estimated and tested for significant differences by multilevel linear logistic regression with sea trips, hauls and individual fish as subsequent levels. To account for imbalances in the number of observations per sea trip and give sea trips equal weight in the analysis, the contribution of each individual fish was weighed according to the number of test-fish collected per sea trip.

The effect of short hauls and the knotless cod end on discards survival was tested as described for the effect of the water filled hopper, considering only those sea trips during which the measures were tested.

Interactive effects of a water filled hopper and fish condition or vessel on discards survival of plaice were tested for all sea trips combined by comparing the estimates for the discards survival probabilities for the groups formed by treatment* vitality index score and treatment*vessel. Survival probabilities per treatment combination were estimated and tested for significant differences by multilevel linear logistic regression with sea trips, hauls and individual fish as subsequent levels.

Effects of the water filled hopper and the short hauls on fish condition were tested by comparing the probability of assigning a test-fish to one of the four vitality index scores among treatment levels. Probabilities of assigning test-fish to one of the four vitality index scores were estimated and tested for differences among the hopper treatments and haul durations by multilevel linear logistic regression with sea trips, hauls and individual fish as subsequent levels.

All estimates and $95 \%$ confidence intervals for the odds ratios were back transformed in survival percentages per treatment or group. A least significance difference (LSD) post-hoc analysis was used to estimate the level of significance between treatments or groups in case a significant effect was detected. All tests were performed at the level of species, plaice or sole. In all cases the fiducial limit was set at $5 \%$. 
Table 4 Description of criteria to score vitality status.

\begin{tabular}{|c|c|}
\hline \multicolumn{2}{|l|}{ Vitallity index } \\
\hline Class & Description \\
\hline A & Fish lively, no visible signs of loss of scale or mucus layer. \\
\hline B & $\begin{array}{l}\text { Fish less lively, minor lesions and some scales missing, mucus layer } \\
\text { affected up to } 20 \% \text { of skin surface area, some point haemorrhaging on the } \\
\text { blind side. }\end{array}$ \\
\hline C & $\begin{array}{l}\text { Fish lethargic, intermediate lesions and some patches without scales, } \\
\text { mucus layer affected up to } 50 \% \text { of skin surface area, several point } \\
\text { haemorrhaging on the blind side. }\end{array}$ \\
\hline D & $\begin{array}{l}\text { Fish lethargic or dead, clear head haemorrhaging, major lesions and } \\
\text { patches without scales, mucus layer affected for more than } 50 \% \text { of the } \\
\text { skin surface area, significant point haemorrhaging on the blind side. }\end{array}$ \\
\hline \multicolumn{2}{|c|}{ External damage scores } \\
\hline Damage & Description ( 1 = present; $0=$ absent) \\
\hline Fin or wings & Fins are damaged or split (including tail fin). Wings in case of rays. \\
\hline$>50 \%$ & $\begin{array}{l}\text { Damage to skin surface, scale or mucus layer at more than } 50 \% \text { of the } \\
\text { dorsal body surface. }\end{array}$ \\
\hline Head haemorrhages & Presence of a haemorrhage in the head of the fish \\
\hline \multicolumn{2}{|c|}{ Hypodermic haemorrhages Presence of a hypodermic haemorrhage } \\
\hline Intestines & $\begin{array}{l}\text { Intestines are protruding or are visible through damaged body tissue of } \\
\text { the fish. }\end{array}$ \\
\hline Wound & Presence of a wound such that flesh is visible. \\
\hline \multicolumn{2}{|c|}{ Reflex impairment scores } \\
\hline Reflex & $\begin{array}{l}\text { Description ( } 1 \text { = impaired; no (clear) response within } 5 \text { s of observation; } 0 \\
=\text { unimpaired; obvious response within } 5 \mathrm{~s} \text { ). }\end{array}$ \\
\hline Body flex & $\begin{array}{l}\text { Fish is held on the palm of the hand with its ventral side up in the air. Fish } \\
\text { actively tries to move head and tail towards each other or wriggle out of } \\
\text { the hand. }\end{array}$ \\
\hline Righting & $\begin{array}{l}\text { Fish is held on the fingers of two hands with the dorsal side touching the } \\
\text { water surface. When released the fish actively rights itself under water. }\end{array}$ \\
\hline Evasion & $\begin{array}{l}\text { Fish is held underwater in an upright position by supporting its ventral side } \\
\text { with the fingers and its dorsal side with the thumbs. When the thumbs are } \\
\text { lifted the fish actively swims away. }\end{array}$ \\
\hline Stabilize & $\begin{array}{l}\text { Untouched fish tries to find a stable position flat on the bottom by } \\
\text { rhythmic and swift movement of the fins and/or body. }\end{array}$ \\
\hline Tail grab & $\begin{array}{l}\text { Fish is gently held by the tailfin between the thumb and index finger. Fish } \\
\text { actively struggles free and swims away. }\end{array}$ \\
\hline Head complex & $\begin{array}{l}\text { Fish moves its operculum or mouth during } 5 \mathrm{~s} \text { of observation while laying } \\
\text { undisturbed under water. }\end{array}$ \\
\hline
\end{tabular}




\section{Results}

\subsection{Survival of control-fish}

The survival of the control-fish for plaice and sole is presented in Table 1 (page 8 ). The survival of control-fish for sole was $\geq 90 \%$ for the three sea trips in which test with sole were done. The survival of control-fish for plaice is $\geq 93 \%$ in all sea trips except trips 5,7 and 8 .

\subsection{The effect of a water filled hopper on discards survival}

\subsubsection{Main effect of a water filled hopper}

The survival curves based on eight sea trips for plaice discards collected from the dry and the water filled hopper and control-fish are presented in Figure 2, survival curves per sea trip are presented in Annex 1. Except for the immediate mortality of test-fish at collection $(t=0)$, the development over time of survival is very similar for both treatments.

For all sea trips combined, no significant effect a water filled hopper with water on plaice discards survival probability could be detected (multilevel linear logistic regression, $p=0.14$, Table 5).

The overall survival curves based on two sea trips for sole discards collected from the dry and the water filled hopper and control-fish are presented in Figure 3. Similar to our observations for plaice, the development over time of survival is very similar for both treatments apart from the initial mortality of test-fish at collection $(t=0)$. A significant effect a water filled hopper with water on sole discards survival probability was detected (multilevel linear logistic regression $p<0.0001$, Table 5). This effect seems mainly present in sea trip 7 as in sea trip 6 most fish died for both treatments (Annex 1).

Table 5 The effect of a water filled hopper on the estimates and 95\% confidence intervals $(\mathrm{Cl})$ for plaice discards survival probability for all sea trips combined and for the individual sea trips. Survival probability estimates differed between the dry and water filled hopper in sea trips 2, 4 and 9 ( $p<$ 0.05).

\begin{tabular}{|c|c|c|c|c|c|c|c|c|}
\hline \multirow[t]{2}{*}{ Species } & \multirow[t]{2}{*}{ Sea trip } & \multicolumn{3}{|c|}{ Dry hopper } & \multicolumn{3}{|c|}{ Water filled hopper } & \multirow[t]{2}{*}{ p-value } \\
\hline & & Estimate & $95 \% \mathrm{Cl} \mathrm{LL}$ & $95 \% \mathrm{Cl} \mathrm{UL}$ & Estimate & $95 \% \mathrm{Cl} \mathrm{LL}$ & $95 \% \mathrm{CI}$ UL & \\
\hline Sole & 6 and 7 & $5 \%$ & $2 \%$ & $10 \%$ & $14 \%$ & $10 \%$ & $21 \%$ & $<0.0001$ \\
\hline \multirow[t]{9}{*}{ Plaice } & $\mathrm{All}^{*}$ & $16 \%$ & $12 \%$ & $19 \%$ & $20 \%$ & $15 \%$ & $25 \%$ & 0.14 \\
\hline & 1 & $15 \%$ & $9 \%$ & $24 \%$ & $18 \%$ & $11 \%$ & $30 \%$ & 0.69 \\
\hline & 2 & $15 \%$ & $11 \%$ & $21 \%$ & $29 \%$ & $25 \%$ & $33 \%$ & 0.0009 \\
\hline & 3 & $12 \%$ & $6 \%$ & $22 \%$ & $15 \%$ & $4 \%$ & $44 \%$ & 0.77 \\
\hline & 4 & $3 \%$ & $1 \%$ & $12 \%$ & $10 \%$ & $6 \%$ & $17 \%$ & 0.03 \\
\hline & 6 & $22 \%$ & $11 \%$ & $38 \%$ & $18 \%$ & $7 \%$ & $41 \%$ & 0.74 \\
\hline & 7 & $20 \%$ & $12 \%$ & $32 \%$ & $10 \%$ & $3 \%$ & $26 \%$ & 0.17 \\
\hline & 8 & $17 \%$ & $7 \%$ & $38 \%$ & $12 \%$ & $4 \%$ & $32 \%$ & 0.26 \\
\hline & 9 & $20 \%$ & $12 \%$ & $33 \%$ & $45 \%$ & $24 \%$ & $68 \%$ & 0.01 \\
\hline
\end{tabular}

\footnotetext{
${ }^{*}$ All sea trips except no. 5 .
} 
Trip 1-2-3-4-6-7-8-9, species = Plaice

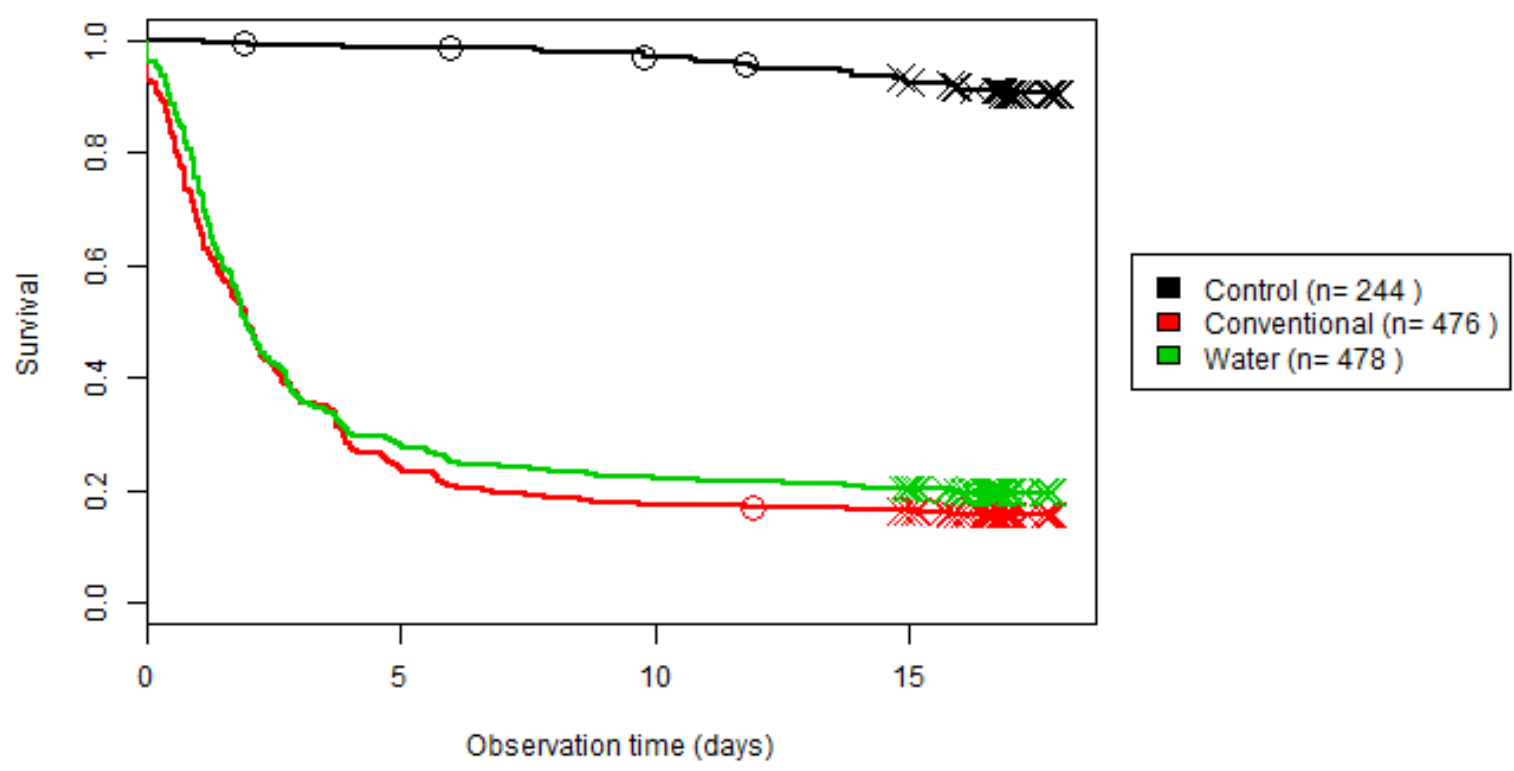

Figure 2. Overall survival of plaice discards over time ( $n=8$ sea trips) for the conventional dry hopper (Conventional), for the water filled hopper (Water) and control-fish (Control). In the figures $X$

represent fish that is alive at the end of the experiment, $O$ represent fish that died due to other causes than fishing mortality (e.g. technical failures) and were excluded from the experiment after $\mathrm{O}$.

Trip 6-7, species $=$ Sole

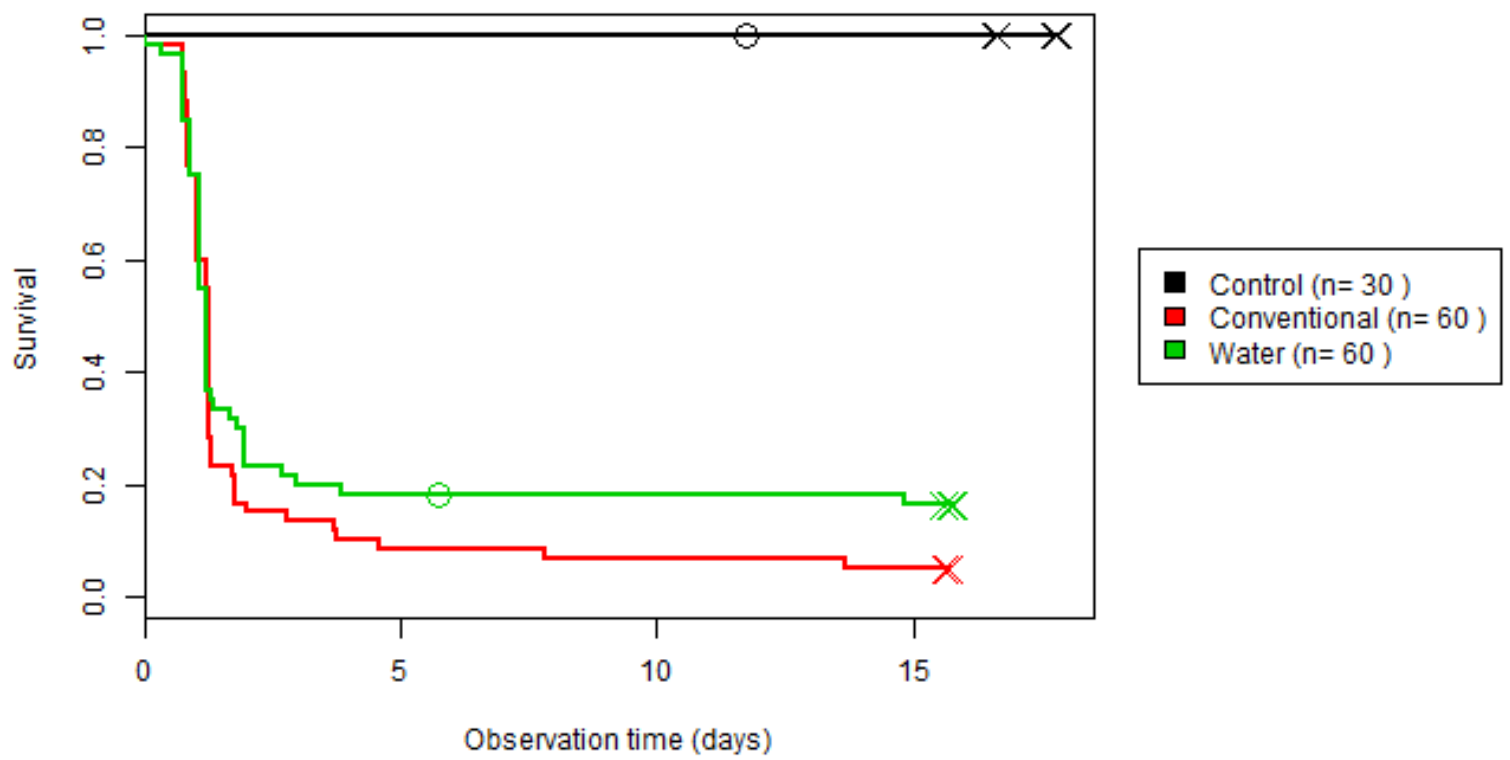

Figure 3. Overall survival of sole discards over time ( $n=2$ sea trips) for the conventional dry hopper (Conventional), for the water filled hopper (Water) and control-fish (Control). In the figures $X$ represent fish that is alive at the end of the experiment, $O$ represent fish that died due to other causes than fishing mortality (e.g. technical failures) and were excluded from the experiment after 0.

\subsubsection{Effects of sea trips and vessels on the effect of the water filled hopper}

Within the individual sea trips, significant differences in discards survival probabilities were detected in sea trips 2, 4 and 9 (Table 5). In all these cases the highest survival probability was observed in the water filled hopper. In all other sea trips during which the water filled hopper was tested, the survival of plaice discards was not significantly different for the water filled and the dry hopper. 
Although the mean plaice discards survival observed for the water filled hopper of vessel 2 is nearly double the survival observed for the other two vessels, no interactive effects of vessel and hopper treatment on plaice discards survival probability were detected (multilevel linear logistic regression $P_{\text {treatment } x \text { vessel }}=0.83$, Table 6 ). The effect of the water hopper on discards survival probability apparently was not influenced by the vessel it was tested on.

Table 6 Vessel effects on the effect of a water filled hopper on plaice discards survival probability.

\begin{tabular}{|c|c|c|c|c|}
\hline \multirow[t]{2}{*}{ Treatment } & \multirow[t]{2}{*}{ Vessel } & \multicolumn{3}{|c|}{ Discards survival probability } \\
\hline & & Estimate & $95 \% \mathrm{Cl} \mathrm{LL}$ & $95 \% \mathrm{Cl}$ UL \\
\hline \multirow[t]{3}{*}{ Dry hopper } & 1 & $16 \%$ & $9 \%$ & $26 \%$ \\
\hline & 2 & $19 \%$ & $14 \%$ & $24 \%$ \\
\hline & 3 & $12 \%$ & $8 \%$ & $19 \%$ \\
\hline \multirow[t]{3}{*}{ Water filled hopper } & 1 & $15 \%$ & $9 \%$ & $25 \%$ \\
\hline & 2 & $28 \%$ & $20 \%$ & $37 \%$ \\
\hline & 3 & $15 \%$ & $8 \%$ & $25 \%$ \\
\hline \multicolumn{2}{|l|}{$P_{\text {treatment }} \times$ Vessel } & 0.83 & & \\
\hline
\end{tabular}

\subsubsection{Effect of a water filled hopper on fish condition}

The probability of assigning a test-fish to one of the four vitality index scores is presented for the dry hopper and the water filled hopper in Table 7. Significant differences in probability estimates were detected between the two hopper treatments. For plaice, the probability to be assigned a vitality index score A was higher while the probability to be assigned a vitality index score D was lower for test-fish collected from the water filled hopper (Multilevel linear logistic regression, Table 7). A similar shift towards a better fish condition was observed among the sole collected from the water filled hopper, but only the higher probability to be assigned a vitality index score B was significant (Table 7). Condition of test-fish, expressed by an individual vitality class score A, B, C or D (Table 4), was positively affected by deployment of a water filled hopper.

Table 7 Probability of vitality index scores per hopper treatment for plaice and sole. Probabilities per vitality class (rows) differ among hopper treatments in case $p<0.05$ (Multilevel linear logistic regression).

\begin{tabular}{|c|c|c|c|c|}
\hline \multirow{2}{*}{$\begin{array}{c}\text { Species } \\
\text { index score }\end{array}$} & \multicolumn{2}{|c|}{$\begin{array}{c}\text { Probability of vitality index scores } \\
\text { Dry hopper }\end{array}$} & \\
\hline \multirow{3}{*}{ Plaice } & A & $8 \%$ & $13 \%$ & 0.003 \\
\cline { 2 - 5 } & B & $27 \%$ & $30 \%$ & 0.35 \\
\hline & C & $31 \%$ & $31 \%$ & 0.88 \\
\hline Sole & D & $34 \%$ & $26 \%$ & 0.001 \\
\hline & A & $5 \%$ & $11 \%$ & 0.13 \\
\hline & C & $28 \%$ & $34 \%$ & 0.001 \\
\hline & D & $47 \%$ & $42 \%$ & 0.21 \\
\hline
\end{tabular}

\subsubsection{Interactive effects of fish condition and a water filled hopper on discards survival probability}

No interactive effects of fish condition and hopper treatment on survival probability of plaice discards were detected (Multilevel linear logistic regression $P_{\text {Treatment }}$ vitality index score $=0.44$, Table 8 ). The survival probability for plaice discards per vitality class did not differ between the dry hopper and water hopper treatment. The effect of a water filled hopper on the survival probability of plaice discards is not affected by fish condition. A significant main effect on fish condition on discards survival probability was detected (Multilevel linear logistic regression $\mathrm{P}$ vitality index score $<0.001$, data not shown). 
Table 8 Discard survival probability estimates for plaice per vitality index class for the dry and water filled hopper treatments. No interactive effects of fish condition (defined by vitality index score) and hopper treatment on survival probability were detected. (Multilevel linear logistic regression $\mathrm{P}_{\text {Treatment } x}$ vitality index score $=0.44$ ).

\begin{tabular}{|c|c|c|c|c|c|c|}
\hline \multirow{3}{*}{$\begin{array}{c}\text { Vitality } \\
\text { index score }\end{array}$} & \multicolumn{6}{|c|}{ Discards survival probability } \\
\hline & \multicolumn{3}{|c|}{ Dry hopper } & \multicolumn{3}{|c|}{ Water filled hopper } \\
\hline & Estimate & $95 \%$ Cl LL & $95 \% \mathrm{Cl}$ UL & Estimate & $95 \%$ Cl LL & $95 \% \mathrm{Cl}$ UL \\
\hline A & $59 \%$ & $44 \%$ & $73 \%$ & $59 \%$ & $46 \%$ & $71 \%$ \\
\hline $\mathrm{B}$ & $31 \%$ & $24 \%$ & $39 \%$ & $27 \%$ & $18 \%$ & $37 \%$ \\
\hline $\mathrm{C}$ & $4 \%$ & $2 \%$ & $10 \%$ & $9 \%$ & $5 \%$ & $15 \%$ \\
\hline $\mathrm{D}$ & $4 \%$ & $2 \%$ & $8 \%$ & $4 \%$ & $1 \%$ & $12 \%$ \\
\hline
\end{tabular}

\subsection{The effect of short hauls on discards survival probability}

\subsubsection{Main effects of short hauls}

The effect of short hauls on plaice discards survival was tested during the first four sea trips (Annex 1 , Figure 4). For all four sea trips combined, short hauls did not affect plaice discards survival (Multilevel linear logistic regression $p=0.77$, Table 9 ). Within each of the four individual sea trips, a significant difference in discards survival probability between the short and conventional haul duration was detected only in the second sea trip (Multilevel linear logistic regression $p=0.002$, Table 9 ). In this sea trip survival probability was highest among test-fish collected from hauls with a conventional duration.

Trip 1-2-3-4, species $=$ Plaice

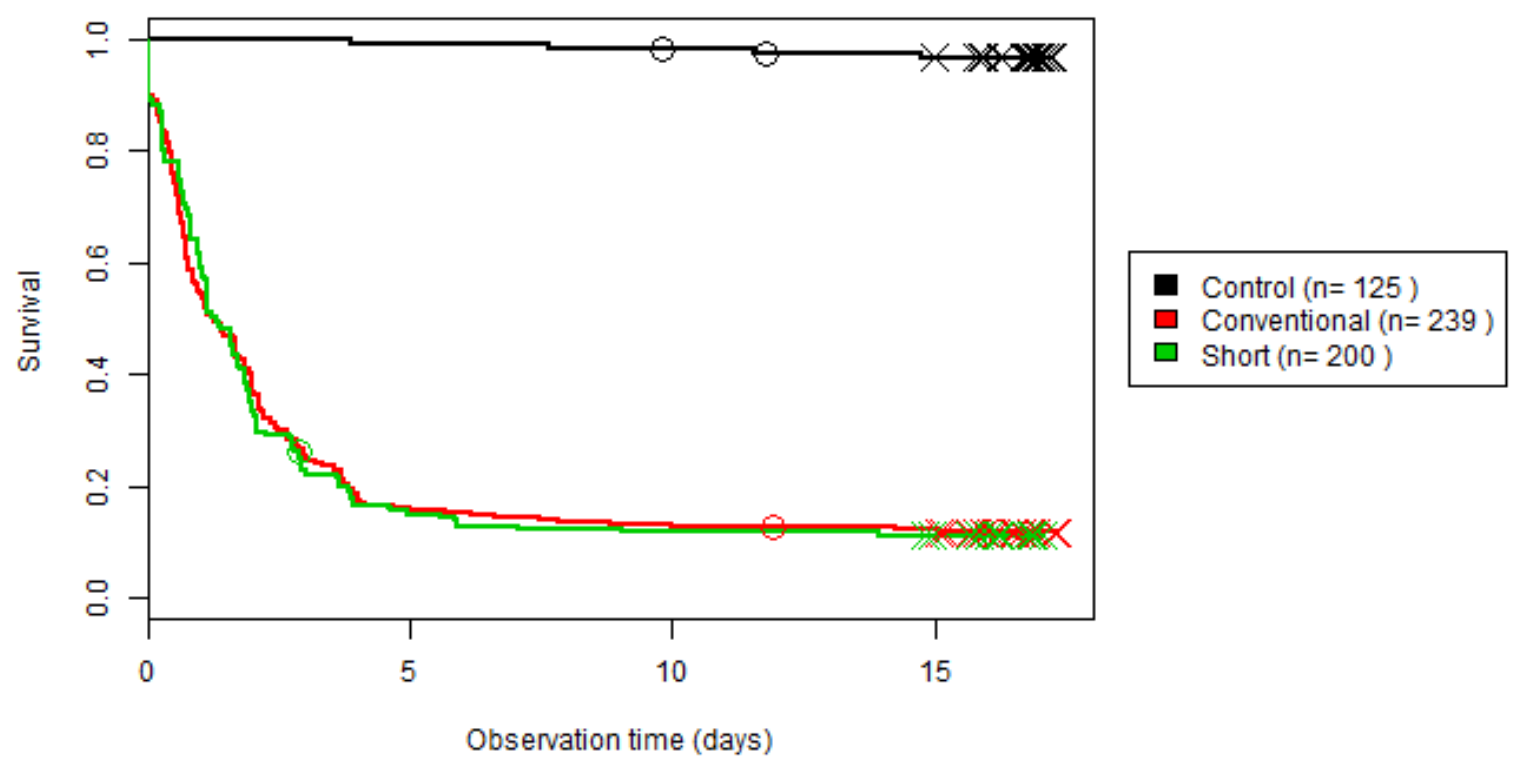

Figure 4. Mean survival of plaice discards over time ( $n=4$ sea trips) for conventional ( $120 \mathrm{~min}$ ) and short hauls $(90 \mathrm{~min})$. In the figures $X$ represent fish that is alive at the end of the experiment, $O$ represent fish that died due to other causes than fishing mortality (e.g. technical failures) and were excluded from the experiment after $\mathrm{O}$. 
Table 9 The effect of short hauls on the estimates and 95\% confidence intervals for plaice discards survival probability for all sea trips combined and for the individual sea trips. Per row, estimates differ between the short and conventional hauls when $p<0.05$.

\begin{tabular}{|c|c|c|c|c|c|c|c|}
\hline \multirow{2}{*}{ Sea trip } & \multicolumn{3}{|c|}{ Conventional haul (120 min) } & \multicolumn{3}{|c|}{ Short haul (90 min) } & \multirow[t]{2}{*}{ p-value } \\
\hline & Estimate & $95 \% \mathrm{Cl} \mathrm{LL}$ & $95 \% \mathrm{Cl} \mathrm{UL}$ & Estimate & $95 \% \mathrm{Cl} \mathrm{LL}$ & $95 \% \mathrm{Cl} \mathrm{UL}$ & \\
\hline 1 to 4 & $11 \%$ & $8 \%$ & $15 \%$ & $11 \%$ & $8 \%$ & $15 \%$ & 0.77 \\
\hline 1 & $15 \%$ & $9 \%$ & $23 \%$ & $17 \%$ & $14 \%$ & $22 \%$ & 0.54 \\
\hline 2 & $15 \%$ & $11 \%$ & $20 \%$ & $7 \%$ & $5 \%$ & $11 \%$ & 0.002 \\
\hline 3 & $12 \%$ & $6 \%$ & $22 \%$ & $10 \%$ & $4 \%$ & $21 \%$ & 0.77 \\
\hline 4 & $3 \%$ & $1 \%$ & $11 \%$ & $8 \%$ & $5 \%$ & $12 \%$ & 0.24 \\
\hline
\end{tabular}

\subsubsection{Effect of short hauls on fish condition}

The probability of assigning a test-fish to one of the four vitality index scores is presented for the short and conventional hauls in Table 10. No differences in probability estimates were detected between the two haul duration treatments (Multilevel linear logistic regression, Table 10). Condition of test-fish, expressed by an individual vitality class score A, B, C or D (Table 4), was not affected by the haul duration treatment.

Table 10 Probability of vitality index scores for plaice for short (90 min) and conventional (120 min) hauls. Probabilities per vitality class (rows) differ among haul durations in case $p<0.05$ (Multilevel linear logistic regression).

\begin{tabular}{|c|c|c|c|c|}
\hline \multirow{2}{*}{$\begin{array}{c}\text { Species } \\
\text { index score }\end{array}$} & \multicolumn{4}{|c|}{$\begin{array}{c}\text { Probability of vitality index scores } \\
\text { Conventional haul (120 min) }\end{array}$} \\
\hline \multirow{2}{*}{ Plaice } & A & $8 \%$ & $6 \%$ & 0.37 \\
& B & $28 \%$ & $24 \%$ & 0.30 \\
\hline & C & $34 \%$ & $35 \%$ & 0.79 \\
\hline & D & $30 \%$ & $35 \%$ & 0.37 \\
\hline
\end{tabular}

\subsubsection{Interactive effects of fish condition and short hauls on discards survival probability}

Discard survival probability estimates for plaice per vitality class are presented for short and conventional hauls in Table 11 . No interactive effects of fish condition and haul duration on survival probability of plaice discards were detected (Multilevel linear logistic regression $P_{\text {Treatment }} \mathrm{x}$ vitality index score $=0.42$, Table 11). The survival probability for plaice discards per vitality class did not differ between short and conventional hauls. The effect of haul duration on the survival probability of plaice discards is not affected by fish condition.

Table 11 Discard survival estimates for conventional and short hauls per vitality class. No interactive effects of fish condition (defined by vitality index score) and haul duration on plaice discard survival probability of plaice discards were detected (Multilevel linear logistic regression PTreatment $\mathrm{x}$ hau I duration $=0.42$ ).

\begin{tabular}{|c|c|c|c|c|c|c|}
\hline \multirow{3}{*}{$\begin{array}{c}\text { Vitality } \\
\text { index score }\end{array}$} & \multicolumn{6}{|c|}{ Discards survival probability } \\
\hline & \multicolumn{3}{|c|}{ Conventional haul (120 min) } & \multicolumn{3}{|c|}{ Short haul (90 min) } \\
\hline & Estimate & $95 \% \mathrm{Cl} \mathrm{LL}$ & $95 \% \mathrm{CI} \mathrm{UL}$ & Estimate & $95 \% \mathrm{Cl} \mathrm{LL}$ & $95 \% \mathrm{CI}$ UL \\
\hline A & $62 \%$ & $42 \%$ & $79 \%$ & $78 \%$ & $58 \%$ & $90 \%$ \\
\hline $\mathrm{B}$ & $30 \%$ & $23 \%$ & $37 \%$ & $20 \%$ & $10 \%$ & $34 \%$ \\
\hline $\mathrm{C}$ & $3 \%$ & $2 \%$ & $7 \%$ & $4 \%$ & $1 \%$ & $11 \%$ \\
\hline D & 0\% & $0 \%$ & $0 \%$ & $0 \%$ & $0 \%$ & $0 \%$ \\
\hline
\end{tabular}




\subsection{Effect of a knotless cod-end on discards survival probability}

Estimates for plaice and sole discards survival probability for the conventional and knotless cod-end are presented Table 12. For plaice no effect of the cod-end on discards survival probability could be detected (Multilevel linear logistic regression $p=0.85$, Table 12). A significant effect of the type of cod-end was detected for sole discards (Multilevel linear logistic regression $p<0.001$, Table 12), based on one surviving test-fish collected from the conventional cod-end and no survival among the test-fish collected from the knotless cod-end.

Table 12 The effect of a knotless cod-end on the estimates and 95\% confidence intervals for plaice and sole discards survival probability.

\begin{tabular}{|c|c|c|c|c|c|c|c|c|}
\hline Species & Sea trip & \multicolumn{4}{|c|}{ Conventional cod-end } & \multicolumn{4}{|c|}{ Knotless cod-end } & p-value \\
& & Estimate & $95 \% \mathrm{Cl}$ LL & $95 \% \mathrm{Cl}$ UL & Estimate $95 \% \mathrm{Cl}$ LL $95 \% \mathrm{Cl}$ UL & \\
\hline Sole & 5 & $3 \%$ & $1 \%$ & $13 \%$ & $0 \%$ & $0 \%$ & $0 \%$ & $<0.001$ \\
\hline Plaice & 5 & $1 \%$ & $0 \%$ & $9 \%$ & $2 \%$ & $0 \%$ & $11 \%$ & 0.85 \\
\hline
\end{tabular}




\section{Discussion}

\subsection{General}

The effect of three measures aimed at increasing survival of discards in pulse-trawl fisheries were investigated. The survival monitoring periods of 15 to 18 days were sufficiently long as mortality had levelled out in all cases before survival monitoring was terminated.

Control-fish were deployed to detect any mortality potentially caused by the experimental procedures instead of being fisheries induced. Survival among control-fish was consistently high at $84 \%$ for plaice over all nine sea trips and $>90 \%$ for sole over three trips. The lower survival among plaice control-fish is caused by three trips with lower than $90 \%$ survival. We attribute the low control-fish survival of $30 \%$ in sea trip 5 to the poor state the control plaice were in prior to the sea trip rather than the experimental procedures, even though this not reflected by the vitality index scores of these fish. The water filled hopper was not tested in this sea trip, so our conclusions on the most important measure to increase discards survival in this study remain entirely unaffected by the low survival among control-fish in sea trip 5.

We cannot explain the lower survival (72\%) among plaice control-fish in sea trips 7 and 8 . However, since the mortality among control-fish started after the mortality in the test-fish had already stabilized, we do not attribute this mortality to the experimental procedures at sea. Although unlikely, we cannot entirely exclude that the experimental procedures caused some additional mortality on top of the fisheries induced mortality, especially among test-fish for plaice. Since survival probability estimates were not correct in case control-fish survival was $<100 \%$, the presented survival probability estimates may be slight underestimations. On the other hand, it cannot be excluded that the presented survival probabilities are slight overestimations because potential post-discarding predation by sea birds and other species was not incorporated in the experiment, although it is unknown to what extent the discarded fish are preyed upon when discarded.

\subsection{Water filled hopper}

The effect of a water filled hopper on discards survival was tested on plaice during eight sea trips and on sole during two sea trips. For all sea trips combined, deployment of a water filled hopper resulted in a significant increase in survival probability for sole discards but not for plaice discards. Although the effect was significant over both trips for sole, only one trip showed a strong increase in survival probability; in the other trip nearly all sole died. Prior to the experiment, we hypothesized that measures that result in an increased survival in plaice discards, also benefits discards survival in other species. The actual increase in survival then remains to be quantified for each individual species. From this study it appears that a significant effect in one species does not necessarily imply that other species also significantly benefit from the same measure. Although a generic positive effect of the water filled hopper was not detected, survival was higher among plaice collected from the water filled hopper for three sea trips. In sea trip 9, the plaice survival probability was at $45 \%$ even $25 \%$ higher than the survival probability observed for the dry hopper. It is seems that a positive effect of a water filled hopper on plaice discards survival occurs under certain circumstances. Indeed, the conditions during the three sea trips that yielded a positive effect where comparable with low wind speeds and limited waves heights, and during sea trip 9 the water temperature was among the lowest in the experiment. Establishing the extent to which an effect of the water filled hopper on discards survival interacts with environmental conditions as well as other factors is beyond the scope of the current study but will be the objective of our further studies using the data collected in the current experiment.

It should be noted that sole was only tested in two sea trips and it cannot be excluded that, in line with our observations on plaice, more tests with sole may results in absence of significant effects in some of the additional sea trips. Clearly, it remains to be established whether the positive effect of a 
water filled hopper on sole discards survival probability is generic or specific for the conditions in which the current tests took place. Surprisingly, for sea trip 6 in which a positive effect for sole was found, no significant effect of the water filled hopper on plaice discards survival was detected. This suggests that the conditions under which a water filled hopper is effective, vary among fish species.

We previously established that survival probability increases with improving condition of the discarded fish (Schram and Molenaar, 2018). To investigate mechanisms that underlie the effect of a water filled hopper, we looked into the effect of this measure on the condition of discarded fish. The larger proportion of fish with an vitality index score A combined with a lower proportion of score D among plaice collected from the water filled hopper compared to the dry hopper, indeed indicates a shift towards a better fish condition as a result of deploying the water filled hopper. We also compared the survival per vitality index scores (classes A, B C and D) for a water filled and dry hopper but detected no interactive effects. Clearly none of the vitality index score classes particularly benefits from using a water filled hopper instead of a dry hopper. This notion combined with the shift towards a better fish condition among fish from the water filled hopper, suggests that the small positive effect of the water filled hopper on discards survival acts through prevention of deterioration of fish condition during codend discharging and catch processing. The proportion of fish in good condition (score A) remains however low, 13\% over all sea trips, among plaice collected from the water filled hopper. This indicates that using a water filled hopper only marginally prevents deterioration of fish condition. It seems that in general fish condition is mainly determined by the preceding capture process rather than the catch-sorting process. In that case the scope to improve fish condition and subsequently increase survival by measures implemented in the catch-sorting process is small. However, focussing on sea trip 9 for which a difference in discards survival probability as large as $25 \%$ was detected between the water filled and dry hopper, reveals a concurring difference in the proportion of fish in good and bad condition. For this trip $40 \%$ of the fish from the water filled hopper scored either a vitality index A or B while this proportion was only $15 \%$ among the fish from the dry hopper. Assuming that there is no variation in fish condition between port- and starboard side catches from the same hauls; fish from both nets arrive on deck in identical condition that cannot improve during catch-sorting, it seems clear that during this trip the water filled hopper prevented to a large extent the deterioration of fish condition during the catch-sorting process.

It should be noted that the water filled hopper does not consistently yield higher discards survival than the dry hopper. For three out of the eight trips during which the water filled hopper was tested, higher survival, although not significantly, was observed for the dry hopper. This may be part of the reason why for all trips combined, no significant effect of the water filled hopper could be detected. It further strengthens the notion that an effect of a water filled hopper on plaice discards survival, either positive or negative, depends on the fishing conditions. The possibility that the water filled hopper can also have a negative effect on discards survival chances should be taken into consideration. Negative effects of a water filled hopper on discards survival may act through depletion of dissolved oxygen since fish are more prone to suffocation in water with low levels of dissolved oxygen than when exposed to air outside the water. Unfortunately we did not systematically measure dissolved oxygen levels during deployment of the water filled hopper and thus have no data that could corroborate this notion. Sloshing of the water in the hopper, observed during heavy seas, may be another possible mechanism underlying a negative effect of the water filled hopper on discards survival. Although not systematically observed nor measured, sloshing the water in the hopper seems to increase physical impacts of fish with the hopper itself as well as other fish, benthic organisms and debris in the catch. It is not unlikely that increased physical impacts lead to deterioration of fish condition and subsequently lower survival probability of discarded fish. Interaction with catch composition, e.g. the amount of pebbles in the catch, then seems likely. Cumulative effects of sloshing and oxygen depletion are unlikely as sloshing would promote oxygenation of the water in the hopper.

Summarizing, it is clear that deployment of a water filled hopper can result in a large increase of survival chances of discarded fish compared to the dry hopper. However, it seems that a water filled hopper only effectively increases discards survival and fish condition under certain specific, yet to be established, conditions. In addition, potential negative effects of a water filled hopper on discards survival cannot be excluded at this point and should not be neglected. Again, it seems that the effect depends on the conditions. 


\subsection{Short hauls and knotless cod-end}

The effect of reduced haul duration, 90 instead of $120 \mathrm{~min}$, on discards survival probability was investigated during four sea trips. We predicted shorter hauls to result higher discards survival through a reduction of capture process related physical impacts on the fish in the cod-ends. Such reduction in physical impacts could be associated with a reduced retention time of fish in the cod-end as well as smaller catches. Surprisingly, for the four sea trips combined, no effect of shorter hauls on discards survival could be detected. In one sea trip, the shorter hauls even resulted to a lower survival among plaice discards. For the other three sea trips no effect was detected. In line with the absence of an effect of short hauls on discards survival, no effect of short hauls on fish condition was detected.

Hauls as short as approximately 60 min were previously found to increase survival of plaice discards in the same fishery (Van der Reijden et al., 2017). This suggests that a reduction of haul duration from 120 to $90 \mathrm{~min}$ is insufficient to sort such effect on discards survival. The relatively small reduction of the haul duration in our study was deliberately chosen as hauls of 90 min may still be practically feasible for the vessel's crew if proven to be very effective in increasing discards survival. While reduction of haul duration below 90 min may lead to a higher increase in discards survival, practical implementation is unrealistic in view of the potential reduction of catches due to the reduction of effective fishing time (by approximately $17 \%$ ) combined with an almost double workload for the crew.

A knotless cod-end was tested during one sea trip only. Survival of plaice and sole discards collected from the knotless cod-end as well as the conventional cod-end which was deployed in the same hauls was very low. In fact, only one of the sole collected from the conventional cod-end survived while those collected from the knotless cod-end all died. Catch composition and environmental conditions could have contributed to this low survival. Nevertheless, based on this single test it seemed clear that the knotless cod-end was not a breakthrough measure with a large positive effect on discards survival. Testing of the knotless cod-end was consequently not continued. 


\section{Conclusions and recommendations}

Deployment of a water filled hopper does not result in higher survival probability for plaice discards than a conventional dry hopper in year-round pulse-trawl fisheries. However, it is clear that for individual trips the deployment of a water filled hopper instead of a dry hopper can result in an increase of survival chances of discarded plaice, but as it seems only under certain specific, yet to be established, conditions. In addition, it cannot be excluded at this point that under certain conditions a water filled hopper has a negative effect on discards survival. Our further analysis of data collected during the current study is expected to provide more insight in conditions that result in either increased or decreased discards survival. It is expected that such insights contribute to optimization of the use of the water filled hopper for the benefit of discards survival chances.

The condition of the individual fish does not interact with the effect of the water filled hopper on discards survival chances; none of the vitality index score classes particularly benefited from using a water filled hopper instead of a dry hopper. However, deployment of a water filled hopper does result in a shift towards a better condition of the discarded fish. This is important because fish in good condition have higher survival chances when discarded than fish in poor conditions. Despite the use of a water filled hopper, the total proportion of fish in good condition within a catch remains small. It should be noted that when conditions during trawling result in in poor condition for a large part of the fish that arrive on deck, fish condition and survival chances cannot be regained by on-board measures. We therefore recommend to prioritize measures aimed at improving fish condition in the trawl to increase discards survival chances.

The two other measures tested showed no potential to increase discards survival chances. Plaice discards survival probability is not increased by a reduction of haul duration from 120 to $90 \mathrm{~min}$. It is unlikely that deployment of a knotless cod-end results in a higher survival probability for plaice discards than a conventional cod-end. 


\section{Acknowledgements}

This study was commissioned by VISNED, The Netherlands. This study was partly funded by the European Union, European Maritime and Fisheries Fund (EMFF). The authors would like to thank the following persons and organisations for their indispensable contributions to this project. The owners, skippers and crews of the UK33, TX3 and GO23 for welcoming researchers on board of their vessels and enabling research at sea. The skippers and crews of the TH10 and OD3 for collecting control-fish at sea. Richard Martens and Wouter van Broekhoven for project management. Pim van Dalen, Ainhoa Blanco, Ad van Gool, Emiel Brummelhuis and Yoeri van Es for all the practical work related to the collection of control-fish, preparation of sea trips and survival monitoring in the laboratory. Van Wijk installaties en constructies BV, Maaskant Shipyards Stellendam BV and Visserij Coöperatie Urk (VCU) for preparing and installing the technical installations at the vessels required for the research. Ewout Blom, Nathalie Steins, J oe Freijser (De Aquanoom), Raoul Kleppe (Wageningen University) and Pim Boute (Wageningen University) for taking part in the sea trips. Mulder Transport BV for transporting the survival monitoring units between vessels and the laboratory. Schreuder Transport BV and Steketee BV for transporting equipment and control-fish to the vessels. Tom Catchpole (CEFAS) for guidance with the protocols for reflex scoring in rays. Sebastian Uhlmann (ILVO) for providing training in reflex scoring in turbot and brill. Jan Jaap Poos, Sander Glorius and Pepijn de Vries for their assistance in data analysis. 


\section{$7 \quad$ Quality Assurance}

Wageningen Marine Research utilises an ISO 9001:2008 certified quality management system (certificate number: 187378-2015-AQ-NLD-RvA). This certificate is valid until 15 September 2018. The organisation has been certified since 27 February 2001. The certification was issued by DNV Certification B.V.

Furthermore, the chemical laboratory at IJ muiden has NEN-EN-ISO/IEC 17025:2005 accreditation for test laboratories with number L097. This accreditation is valid until $1^{\text {th }}$ of April 2021 and was first issued on 27 March 1997. Accreditation was granted by the Council for Accreditation. The chemical laboratory at IJ muiden has thus demonstrated its ability to provide valid results according a technically competent manner and to work according to the ISO 17025 standard. The scope (L097) of de accredited analytical methods can be found at the website of the Council for Accreditation (www.rva.nl).

On the basis of this accreditation, the quality characteristic $Q$ is awarded to the results of those components which are incorporated in the scope, provided they comply with all quality requirements. The quality characteristic $Q$ is stated in the tables with the results. If, the quality characteristic $Q$ is not mentioned, the reason why is explained.

The quality of the test methods is ensured in various ways. The accuracy of the analysis is regularly assessed by participation in inter-laboratory performance studies including those organized by QUASIMEME. If no inter-laboratory study is available, a second-level control is performed. In addition, a first-level control is performed for each series of measurements.

In addition to the line controls the following general quality controls are carried out:

- Blank research.

- Recovery.

- Internal standard

- Injection standard.

- Sensitivity.

The above controls are described in Wageningen Marine Research working instruction ISW 2.10.2.105. If desired, information regarding the performance characteristics of the analytical methods is available at the chemical laboratory at IJ muiden.

If the quality cannot be guaranteed, appropriate measures are taken. 


\section{References}

Benoît, H.P., Plante, S., Kroiz, M., Hurlbut, T. 2013. A comparative analysis of marine fish species susceptibilities to discard mortality: effects of environmental factors, individual traits, and phylogeny. ICES J ournal of Marine Science $70(1,1), 99-113$.

Enever, R., Catchpole, T.L., Ellis, J.R., Grant, A. 2009. The survival of skates (Rajidae) caught by demersal trawlers fishing in UK waters. Fisheries Research 97 (1-2).

European Union. 2013. REGULATION (EU) No 1380/2013 OF THE EUROPEAN PARLIAMENT AND OF THE COUNCIL of 11 December 2013 on the Common Fisheries Policy, amending Council Regulations (EC) No 1954/2003 and (EC) No 1224/2009 and repealing Council Regulations (EC) No 2371/2002 and (EC) No 639/2004 and Council Decision 2004/585/EC. Official Journal of the European Union, L354/22

Kaplan, E.L., Meier, P. 2012. Nonparametric Estimation from Incomplete Observations, J ournal of the American Statistical Association, 53:282, 457-481,

Schram, E., Molenaar, P. 2018. Discards survival probabilities of flatfish and rays in North Sea pulsetrawl fisheries. Wageningen Marine Research Report C037/18..

Van der Reijden, K. J., Molenaar, P., Chen, C., Uhlmann, S.S., Goudswaard, P.C. Van Marlen, B. 2017. Survival of undersized plaice (Pleuronectes platessa), sole (Solea solea), and dab (Limanda limanda) in North Sea pulse-trawl fisheries. ICES J ournal of Marine Science 74(6), 1672-1680.

Van Marlen, B., Molenaar, P., Van der Reijden, K.J., Goudswaard, P.C., Bol, R.A., Glorius, S.T., Theunynck, R., Uhlmann, S.S. 2016. Overleving van discard platvis - Vaststellen en verhogen. I MARES rapport C180/15, I MARES Wageningen UR. 


\section{Justification}

Report C038/18

Project Number: 4311400003

The scientific quality of this report has been peer reviewed by a colleague scientist and a member of the Management Team of Wageningen Marine Research

Approved: $\quad$ Dr. ir. N.A. Steins

Programme Manager

Signature:

Date:

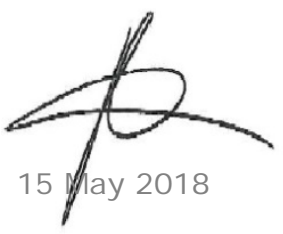

Approved:

Signature:

Date:

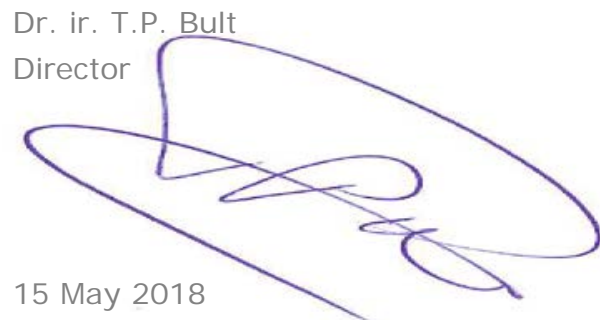




\section{Annex 1: Survival per trip}

\section{Trip 1}

\begin{tabular}{|c|c|c|c|c|c|c|c|c|c|c|c|}
\hline Trip & Vessel & Year & Month & Week & \begin{tabular}{|c|} 
Air \\
temperatur \\
$e\left({ }^{\circ} \mathrm{C}\right)$ \\
\end{tabular} & $\begin{array}{c}\text { Water } \\
\text { temperatur } \\
\mathrm{e}\left({ }^{\circ} \mathrm{C}\right)\end{array}$ & $\begin{array}{c}\text { Wind speed } \\
\text { (Bft) }\end{array}$ & $\begin{array}{c}\text { Wave } \\
\text { height }(\mathrm{m})\end{array}$ & $\begin{array}{l}\text { Catch } \\
\text { processing } \\
(\mathrm{min}) \\
\end{array}$ & $\begin{array}{l}\text { Haul } \\
\text { duration } \\
\text { (min) }\end{array}$ & $\begin{array}{l}\text { Fishing } \\
\text { depth ( } \mathrm{m})\end{array}$ \\
\hline 1 & UK33 & 2017 & May & 18 & - & $9-12$ & $2-5$ & $0.5-2.0$ & 25 & $85-135$ & $26-28$ \\
\hline
\end{tabular}

\begin{tabular}{|c|c|c|c|}
\hline \multicolumn{4}{|c|}{ Survival of plaice } \\
\hline \#Control & \# Test & \# Water & \# Short \\
\hline $100 \%$ & $\mathbf{1 5 \%}$ & $\mathbf{1 8 \%}$ & $\mathbf{1 1 \%}$ \\
\hline
\end{tabular}

Trip 1 - species Plaice

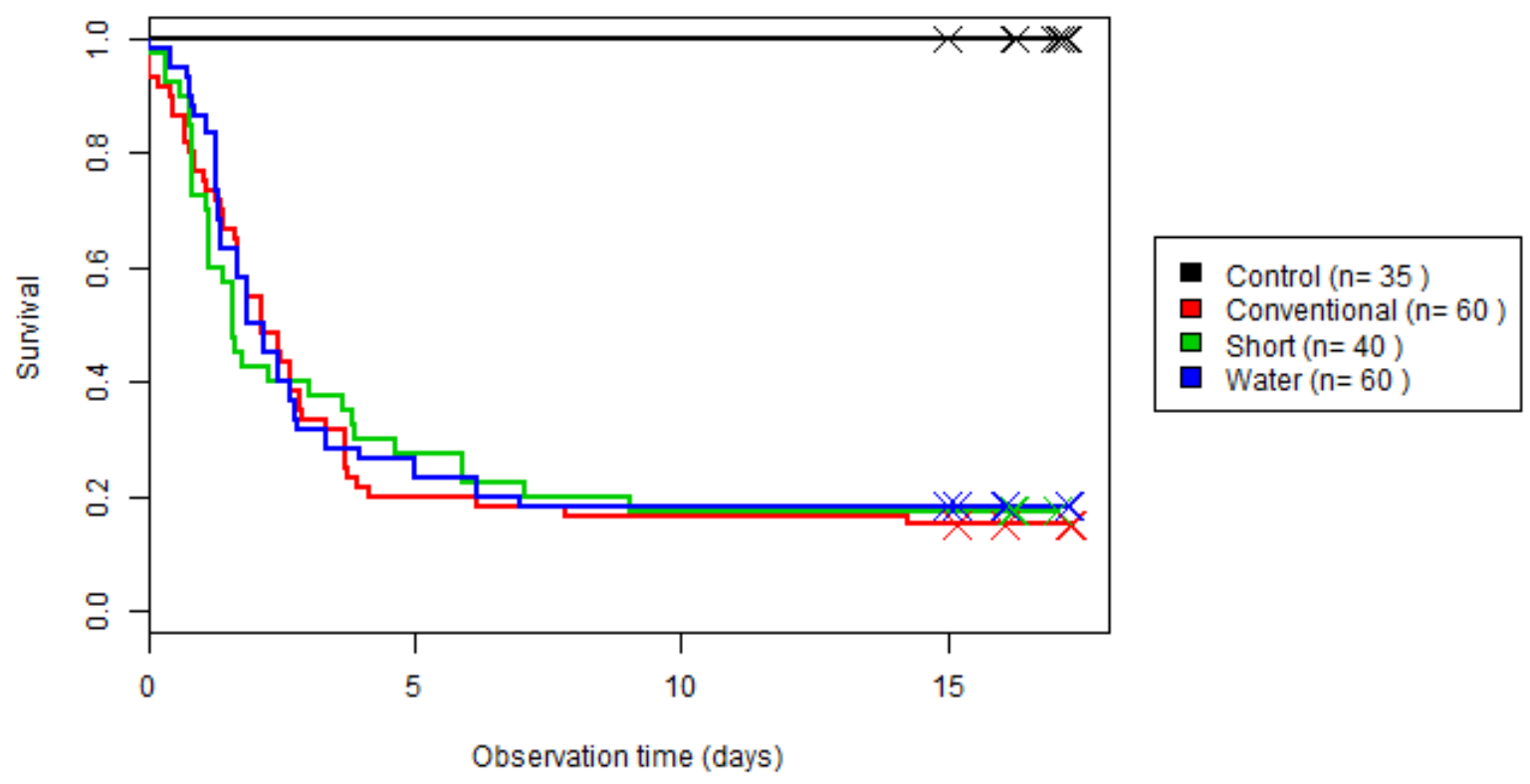




\section{Trip 2}

\begin{tabular}{|c|c|c|c|c|c|c|c|c|c|c|c|}
\hline Trip & Vessel & Year & Month & Week & $\begin{array}{c}\text { Air } \\
\text { temperatur } \\
e\left({ }^{\circ} \mathrm{C}\right)\end{array}$ & $\begin{array}{c}\text { Water } \\
\text { temperatur } \\
e\left({ }^{\circ} \mathrm{C}\right)\end{array}$ & $\begin{array}{c}\text { Wind speed } \\
\text { (Bft) }\end{array}$ & $\begin{array}{c}\text { Wave } \\
\text { height }(\mathrm{m})\end{array}$ & $\begin{array}{c}\text { Catch } \\
\text { processing } \\
(\mathrm{min}) \\
\end{array}$ & $\begin{array}{c}\text { Haul } \\
\text { duration } \\
\text { (min) } \\
\end{array}$ & $\begin{array}{l}\text { Fishing } \\
\text { depth ( } \mathrm{m} \text { ) }\end{array}$ \\
\hline 2 & GO23 & 2017 & May & 21 & $14-18$ & $12-13$ & $1-4$ & $0.2-0.5$ & 24 & $90-120$ & $39-50$ \\
\hline
\end{tabular}

\begin{tabular}{|c|c|c|c|}
\hline \multicolumn{4}{|c|}{ Survival of Plaice } \\
\hline \#Control & \# Test & \# Water & \# Short \\
\hline $97 \%$ & $\mathbf{1 5 \%}$ & $\mathbf{2 9} \%$ & $\mathbf{1 7 \%}$ \\
\hline
\end{tabular}

Trip 2 - species Plaice

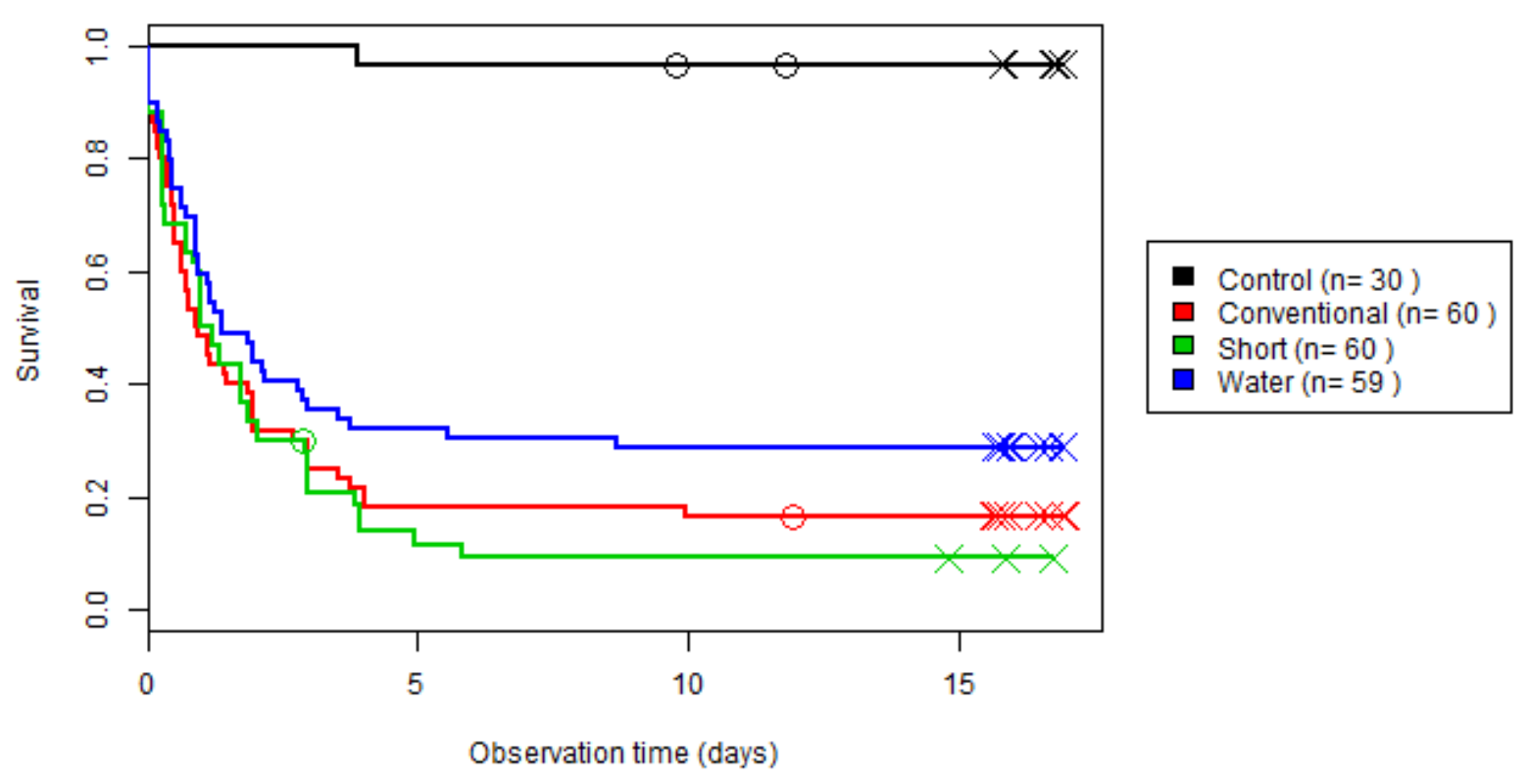




\section{Trip 3}

\begin{tabular}{|c|c|c|c|c|c|c|c|c|c|c|c|}
\hline Trip & Vessel & Year & Month & Week & \begin{tabular}{|c|} 
Air \\
temperatur \\
$\mathrm{e}\left({ }^{\circ} \mathrm{C}\right)$ \\
\end{tabular} & $\begin{array}{c}\text { Water } \\
\text { temperatur } \\
e\left({ }^{\circ} \mathrm{C}\right) \\
\end{array}$ & $\begin{array}{c}\text { Wind speed } \\
\text { (Bft) }\end{array}$ & $\begin{array}{c}\text { Wave } \\
\text { height }(\mathrm{m})\end{array}$ & \begin{tabular}{|c|} 
Catch \\
processing \\
$(\mathrm{min})$ \\
\end{tabular} & $\begin{array}{l}\text { Haul } \\
\text { duration } \\
\text { (min) }\end{array}$ & $\begin{array}{c}\text { Fishing } \\
\text { depth ( } \mathrm{m})\end{array}$ \\
\hline 3 & TX3 & 2017 & June & 24 & $15-20$ & $14-15$ & $1-2$ & $0.1-0.5$ & 18 & $90-125$ & $22-25$ \\
\hline
\end{tabular}

\begin{tabular}{|c|c|c|c|}
\hline \multicolumn{4}{|c|}{ Survival of Plaice } \\
\hline \#Control & \# Test & \# Water & \# Short \\
\hline $100 \%$ & $12 \%$ & $15 \%$ & $10 \%$ \\
\hline
\end{tabular}

Trip 3 - species Plaice

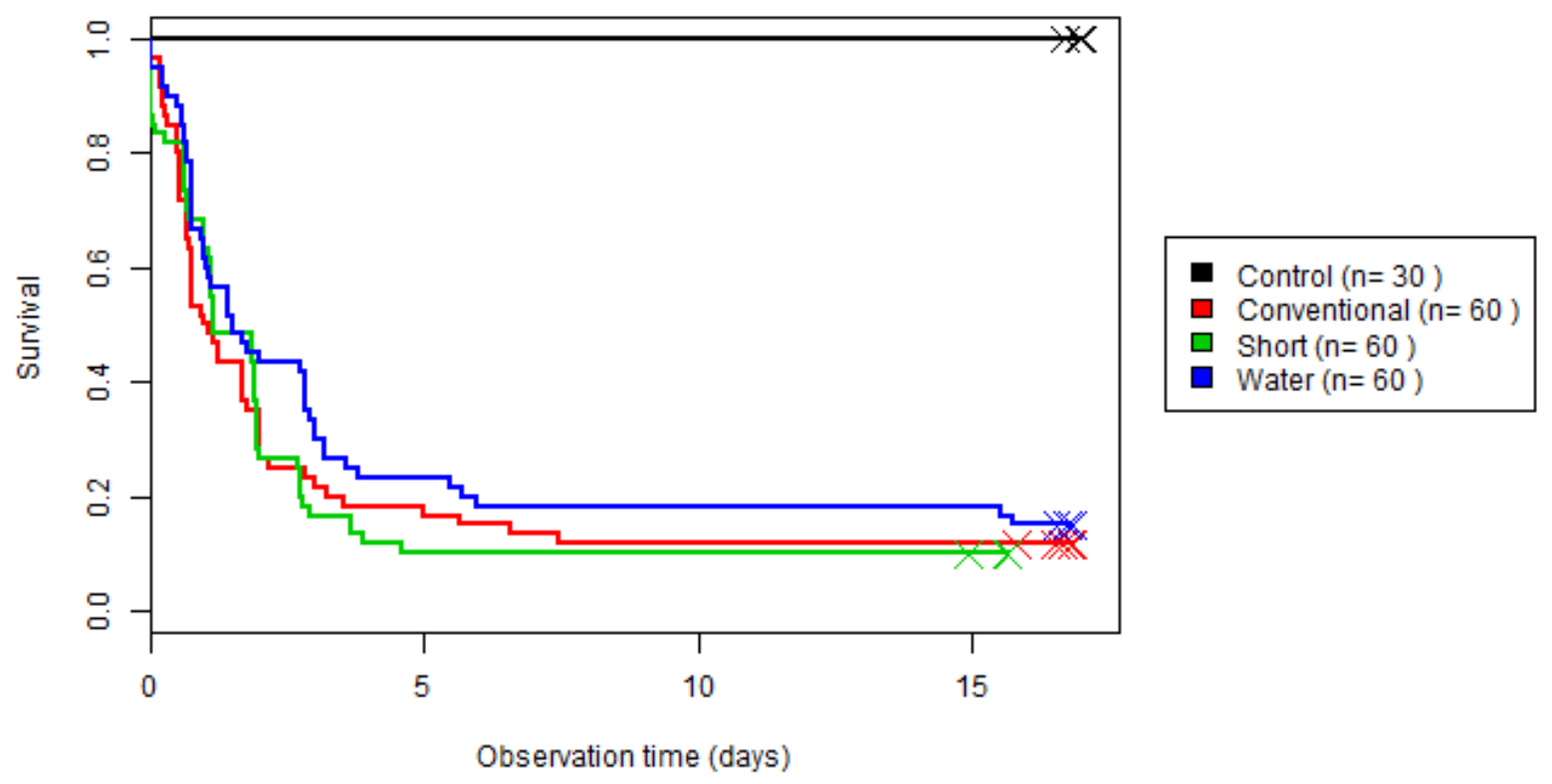




\section{Trip 4}

\begin{tabular}{|c|c|c|c|c|c|c|c|c|c|c|c|}
\hline Trip & Vessel & Year & Month & Week & $\begin{array}{c}\text { Air } \\
\text { temperatur } \\
\mathrm{e}\left({ }^{\circ} \mathrm{C}\right) \\
\end{array}$ & $\begin{array}{c}\text { Water } \\
\text { temperatur } \\
\mathrm{e}\left({ }^{\circ} \mathrm{C}\right) \\
\end{array}$ & $\begin{array}{c}\text { Wind speed } \\
\text { (Bft) }\end{array}$ & $\begin{array}{c}\text { Wave } \\
\text { height ( } \mathrm{m} \text { ) }\end{array}$ & $\begin{array}{l}\text { Catch } \\
\text { processing } \\
(\min ) \\
\end{array}$ & $\begin{array}{l}\text { Haul } \\
\text { duration } \\
(\min ) \\
\end{array}$ & $\begin{array}{c}\text { Fishing } \\
\text { depth ( } \mathrm{m} \text { ) }\end{array}$ \\
\hline 4 & TX3 & 2017 & July & 28 & $15-21$ & $16-17$ & $1-6$ & $0.2-1.0$ & 18 & $90-120$ & $28-40$ \\
\hline
\end{tabular}

\begin{tabular}{|c|c|c|c|}
\hline \multicolumn{4}{|c|}{ Survival of Plaice } \\
\hline \#Control & \# Test & \# Water & \# Short \\
\hline $90 \%$ & $\mathbf{3 \%}$ & $\mathbf{1 0 \%}$ & $\mathbf{8 \%}$ \\
\hline
\end{tabular}

Trip 4 - species Plaice

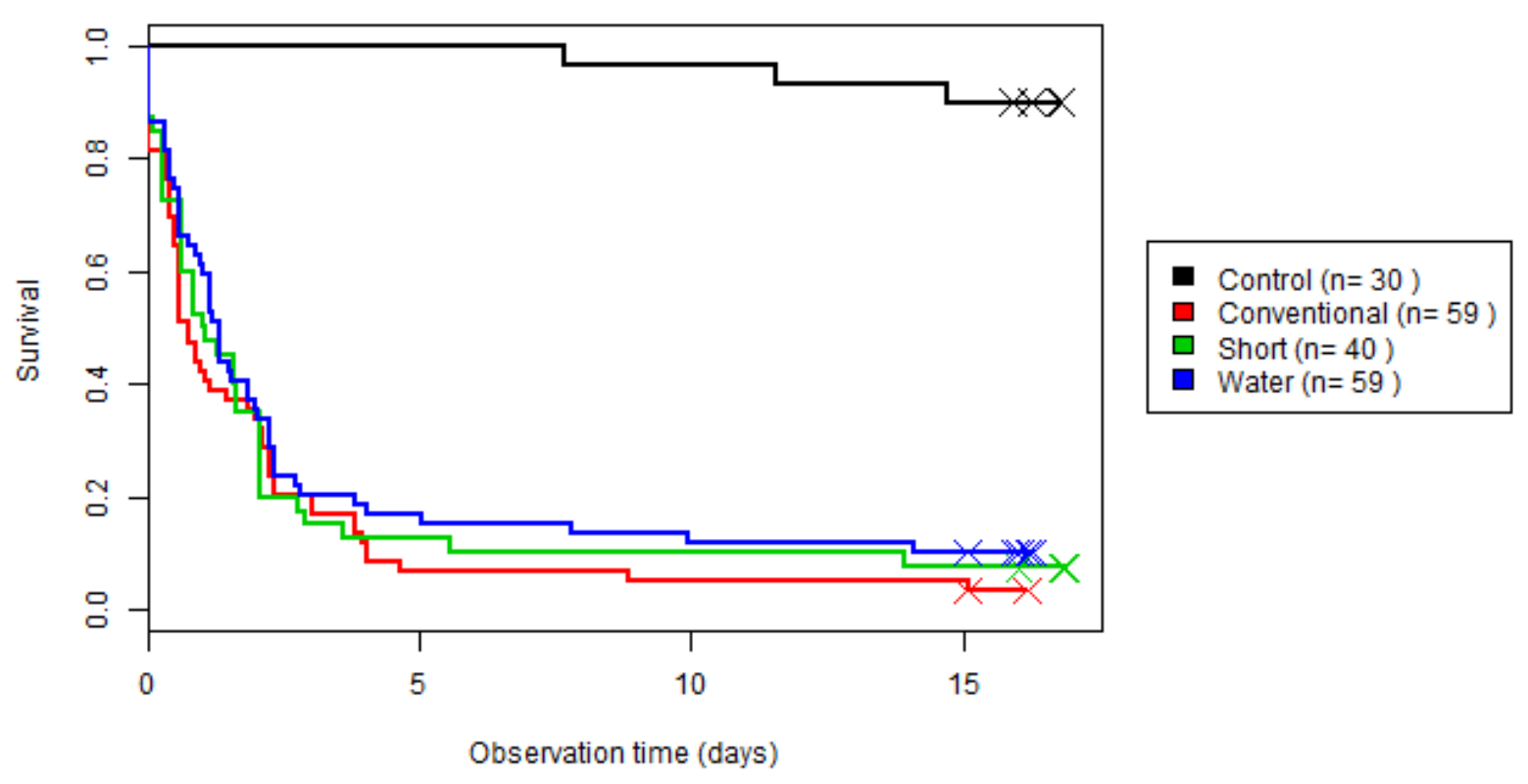




\section{Trip 5}

\begin{tabular}{|c|c|c|c|c|c|c|c|c|c|c|c|}
\hline Trip & Vessel & Year & Month & Week & $\begin{array}{c}\text { Air } \\
\text { temperatur } \\
e\left({ }^{\circ} \mathrm{C}\right)\end{array}$ & $\begin{array}{c}\text { Water } \\
\text { temperatur } \\
e\left({ }^{\circ} \mathrm{C}\right)\end{array}$ & $\begin{array}{c}\text { Wind speed } \\
\text { (Bft) }\end{array}$ & $\begin{array}{c}\text { Wave } \\
\text { height }(\mathrm{m})\end{array}$ & $\begin{array}{l}\text { Catch } \\
\text { processing } \\
\text { (min) }\end{array}$ & $\begin{array}{l}\text { Haul } \\
\text { duration } \\
\text { (min) }\end{array}$ & $\begin{array}{c}\text { Fishing } \\
\text { depth ( } \mathrm{m})\end{array}$ \\
\hline 5 & UK33 & 2017 & Sept & 36 & $15-18$ & 18 & 4-5 & $0.5-1.0$ & 21 & $120-130$ & $26-37$ \\
\hline
\end{tabular}

\begin{tabular}{|c|c|c|c|c|c|c|c|}
\hline \multicolumn{3}{|c|}{ Survival of Plaice } & \multicolumn{3}{c|}{ Survival of Sole } \\
\hline \#Control & \# Test & \# Knotless & & \#Control & \# Test & \# Knotless & \\
\hline $30 \%$ & $\mathbf{1 \%}$ & $\mathbf{2 \%}$ & & $90 \%$ & $\mathbf{3} \%$ & $\mathbf{0 \%}$ & \\
\hline
\end{tabular}

Trip 5 - species Plaice

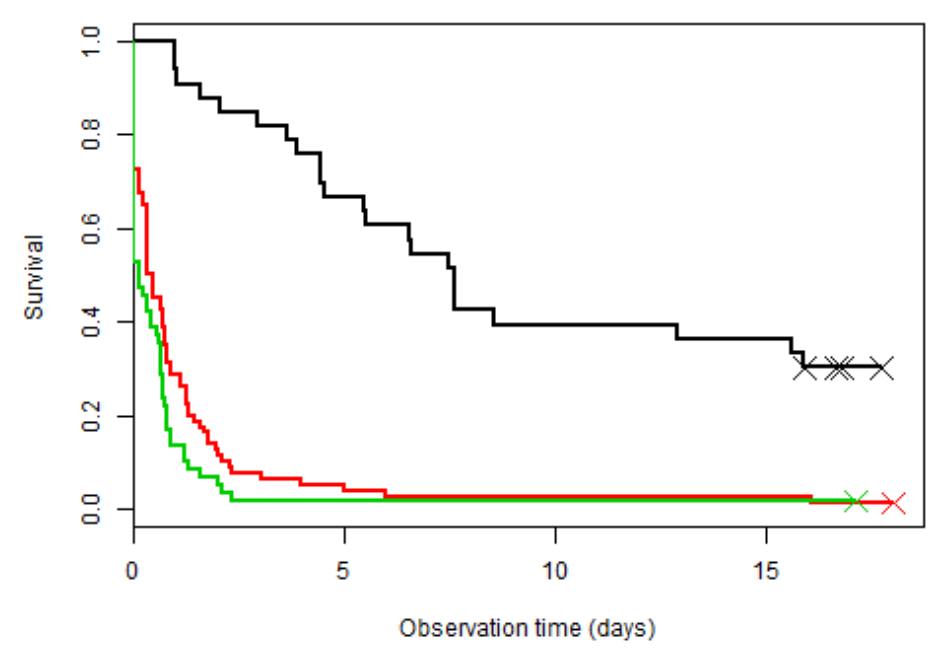

- Control $(n=33)$

Conventional $(n=80)$

$\square$ Knotless $(n=59)$

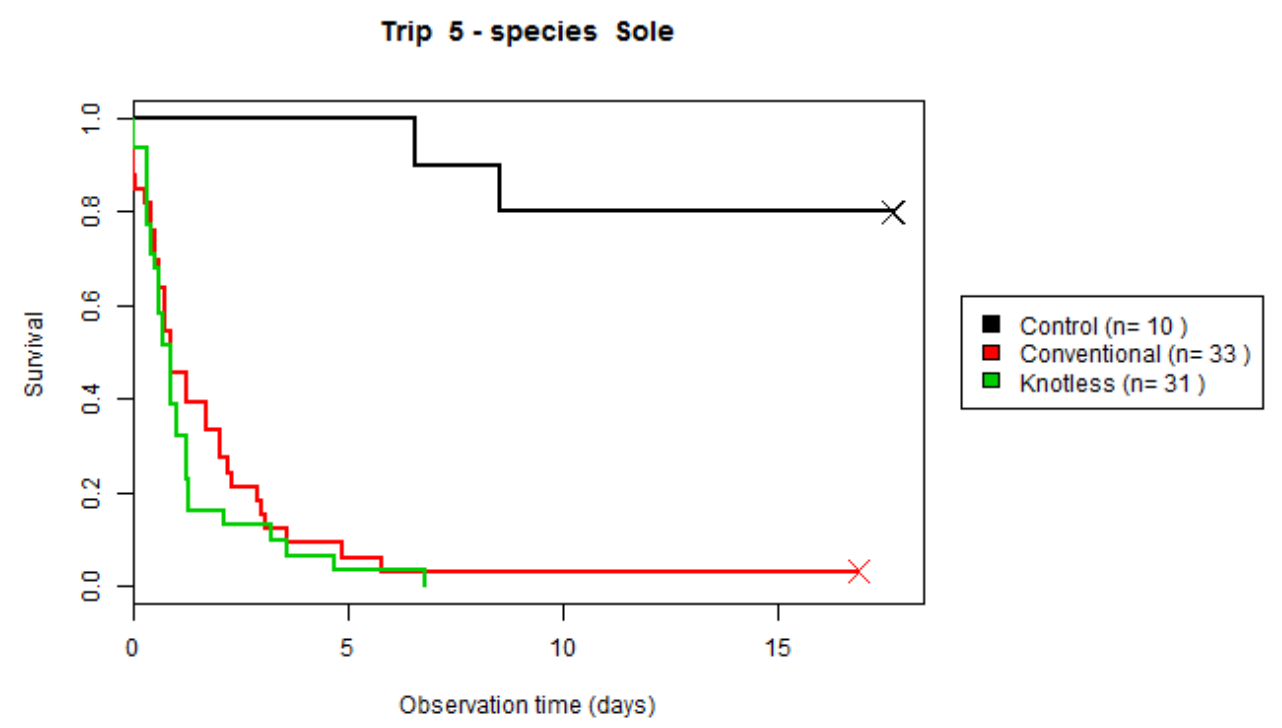




\section{Trip 6}

\begin{tabular}{|c|c|c|c|c|c|c|c|c|c|c|c|}
\hline Trip & Vessel & Year & Month & Week & \begin{tabular}{|c|} 
Air \\
temperatur \\
$\mathrm{e}\left({ }^{\circ} \mathrm{C}\right)$ \\
\end{tabular} & $\begin{array}{c}\text { Water } \\
\text { temperatur } \\
e\left({ }^{\circ} \mathrm{C}\right)\end{array}$ & $\mid \begin{array}{c}\text { Wind speed } \\
\text { (Bft) }\end{array}$ & $\begin{array}{c}\text { Wave } \\
\text { height ( } \mathrm{m} \text { ) }\end{array}$ & \begin{tabular}{|c|c|c|c|} 
Catch \\
processing \\
(min) \\
\end{tabular} & $\begin{array}{l}\text { Haul } \\
\text { duration } \\
(\text { min) } \\
\end{array}$ & $\begin{array}{l}\text { Fishing } \\
\text { depth ( } \mathrm{m} \text { ) }\end{array}$ \\
\hline 6 & TX3 & 2017 & Oct & 44 & $13-15$ & 13-15 & $3-4$ & $1.0-1.2$ & 20 & $120-130$ & $30-31$ \\
\hline
\end{tabular}

\begin{tabular}{|c|c|c|c|c|c|c|c|}
\hline \multicolumn{3}{|c|}{ Survival of Plaice } & \multicolumn{3}{c|}{ Survival of Sole } \\
\hline \#Control & \# Test & \# Water & & \#Control & \# Test & \# Water & \\
\hline $100 \%$ & $\mathbf{2 2} \%$ & $\mathbf{1 8 \%}$ & & $100 \%$ & $\mathbf{1 0} \%$ & $\mathbf{2 5 \%}$ & \\
\hline
\end{tabular}

Trip 6 - species Plaice

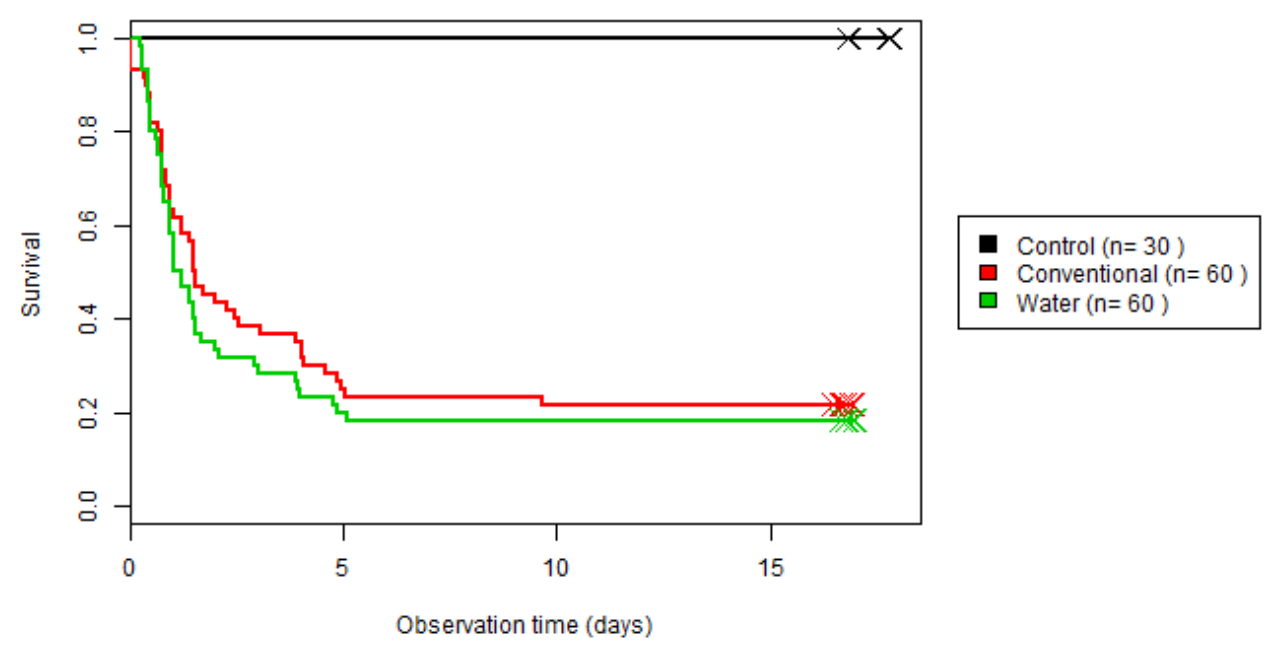

Trip 6 - species Sole

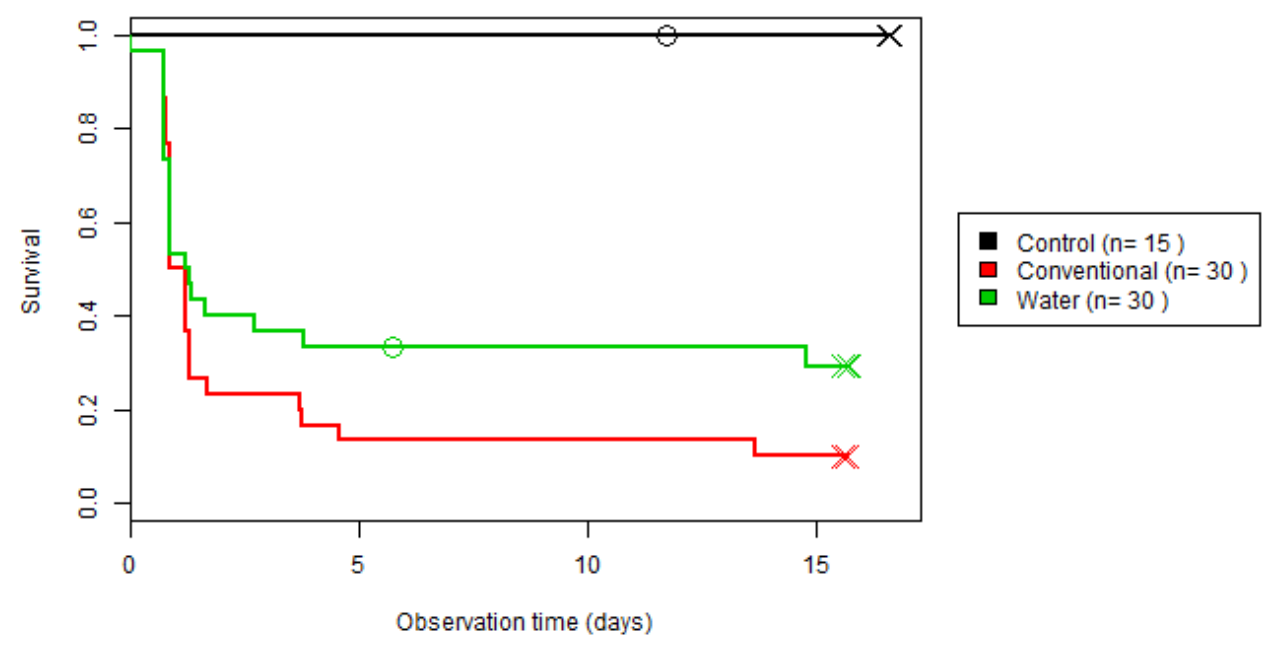




\section{Trip 7}

\begin{tabular}{|c|c|c|c|c|c|c|c|c|c|}
\hline Trip & Vessel & Year & Month & Week & $\begin{array}{c}\text { Air } \\
\text { temperatur } \\
e\left({ }^{\circ} \mathrm{C}\right)\end{array}$ & $\begin{array}{c}\text { Water } \\
\text { temperatur } \\
e\left({ }^{\circ} \mathrm{C}\right)\end{array}$ & $\begin{array}{c}\text { Wind speed } \\
\text { (Bft) }\end{array}$ & $\begin{array}{c}\text { Wave } \\
\text { height (m) }\end{array}$ & $\begin{array}{c}\text { Catch } \\
\text { processing } \\
\text { depth }\end{array}$ \\
\hline 7 & GO23 & 2017 & Dec & 49 & $6-9$ & $11-12$ & $3-5$ & $1.0-2.0$ & 33 \\
\hline
\end{tabular}

\begin{tabular}{|c|c|c|c|c|c|c|}
\hline \multicolumn{3}{|c|}{ Survival of Plaice } & \multicolumn{3}{c|}{ Survival of Sole } \\
\hline \#Control & \# Test & \# Water & & \#Control & \# Test & \# Water \\
\hline $72 \%$ & $\mathbf{2 0 \%}$ & $\mathbf{1 0 \%}$ & & $100 \%$ & $\mathbf{0} \%$ & $\mathbf{3} \%$ \\
\hline
\end{tabular}

Trip 7 - species Plaice

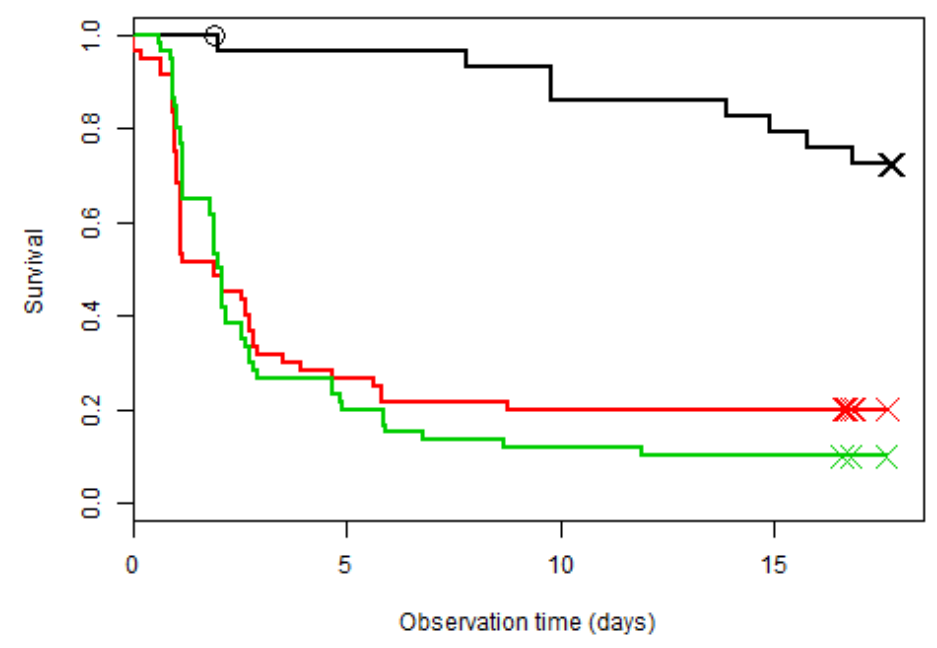

- Control $(n=30)$

Conventional $(n=60)$

Water $(n=60)$

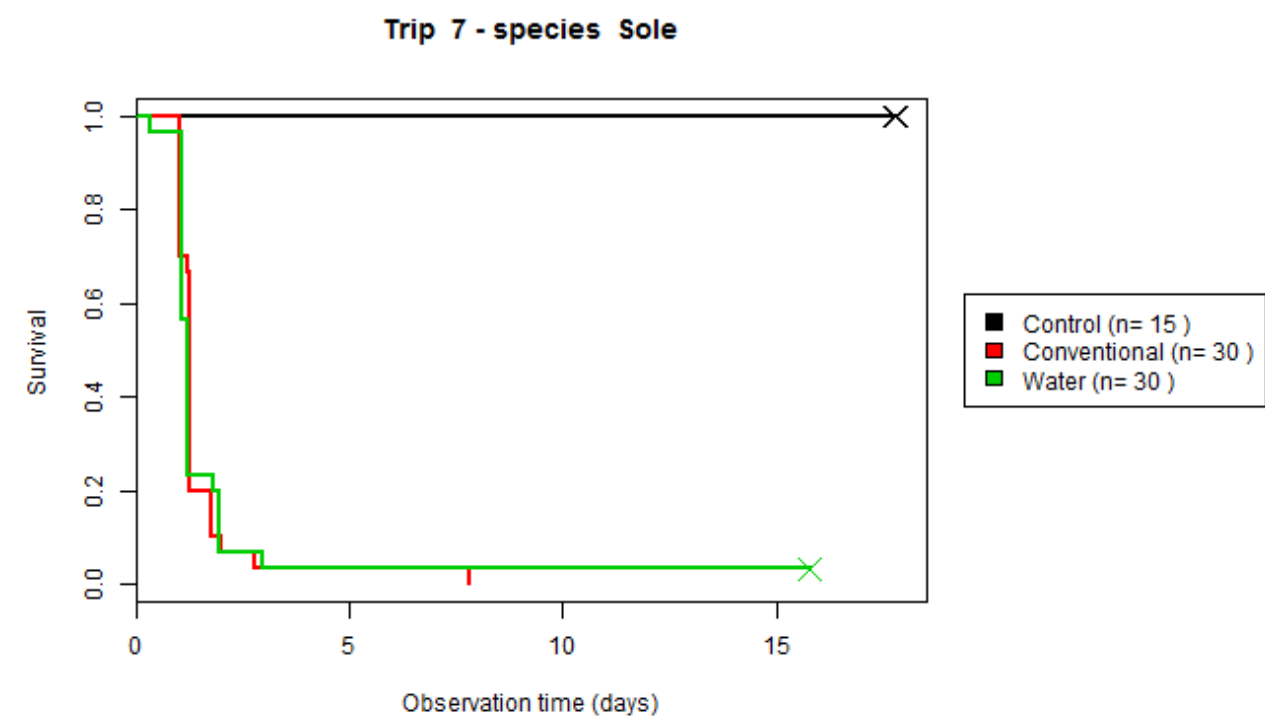




\section{Trip 8}

\begin{tabular}{|c|c|c|c|c|c|c|c|c|c|c|c|}
\hline Trip & Vessel & Year & Month & Week & $\begin{array}{c}\text { Air } \\
\text { temperatur } \\
e\left({ }^{\circ} \mathrm{C}\right) \\
\end{array}$ & $\begin{array}{c}\text { Water } \\
\text { temperatur } \\
\mathrm{e}\left({ }^{\circ} \mathrm{C}\right)\end{array}$ & $\begin{array}{c}\text { Wind speed } \\
\text { (Bft) }\end{array}$ & $\begin{array}{c}\text { Wave } \\
\text { height }(\mathrm{m})\end{array}$ & $\begin{array}{c}\text { Catch } \\
\text { processing } \\
(\mathrm{min}) \\
\end{array}$ & $\begin{array}{l}\text { Haul } \\
\text { duration } \\
\text { (min) }\end{array}$ & $\begin{array}{l}\text { Fishing } \\
\text { depth ( } \mathrm{m})\end{array}$ \\
\hline 8 & UK33 & 2018 & Jan & 4 & 8 & $6-7$ & $5-6$ & $1.0-1.7$ & 33 & 120 & $28-35$ \\
\hline
\end{tabular}

\begin{tabular}{|c|c|c|c|}
\hline \multicolumn{4}{|c|}{ Survival of Plaice } \\
\hline \#Control & \# Test & \# Water & \\
\hline $72 \%$ & $17 \%$ & $12 \%$ & \\
\hline
\end{tabular}

Trip 8 - species Plaice

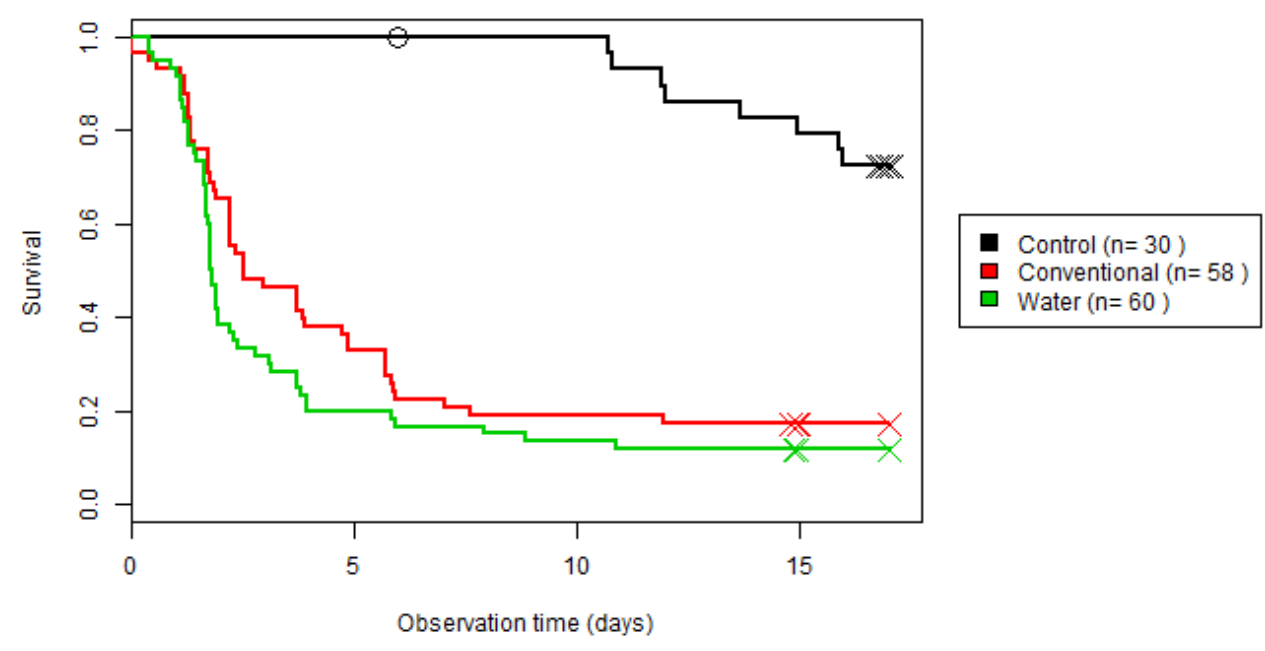




\section{Trip 9}

\begin{tabular}{|c|c|c|c|c|c|c|c|c|c|c|c|}
\hline Trip & Vessel & Year & Month & Week & $\begin{array}{c}\text { Air } \\
\text { temperatur } \\
e\left({ }^{\circ} \mathrm{C}\right)\end{array}$ & $\begin{array}{c}\text { Water } \\
\text { temperatur } \\
\mathrm{e}\left({ }^{\circ} \mathrm{C}\right)\end{array}$ & $\begin{array}{c}\text { Wind speed } \\
\text { (Bft) }\end{array}$ & $\begin{array}{c}\text { Wave } \\
\text { height }(\mathrm{m})\end{array}$ & $\begin{array}{l}\text { Catch } \\
\text { processing } \\
\text { (min) }\end{array}$ & $\begin{array}{l}\text { Haul } \\
\text { duration } \\
\text { (min) }\end{array}$ & $\begin{array}{c}\text { Fishing } \\
\text { depth ( } \mathrm{m})\end{array}$ \\
\hline 9 & GO23 & 2018 & Feb & 8 & 6 & $7-8$ & $3-4$ & $0.5-1.0$ & 24 & $110-120$ & $40-45$ \\
\hline
\end{tabular}

\begin{tabular}{|c|c|c|c|}
\hline \multicolumn{4}{|c|}{ Survival of Plaice } \\
\hline \#Control & \# Test & \# Water & \\
\hline $93 \%$ & $\mathbf{2 0} \%$ & $\mathbf{4 5 \%}$ & \\
\hline
\end{tabular}

Trip 9 - species Plaice

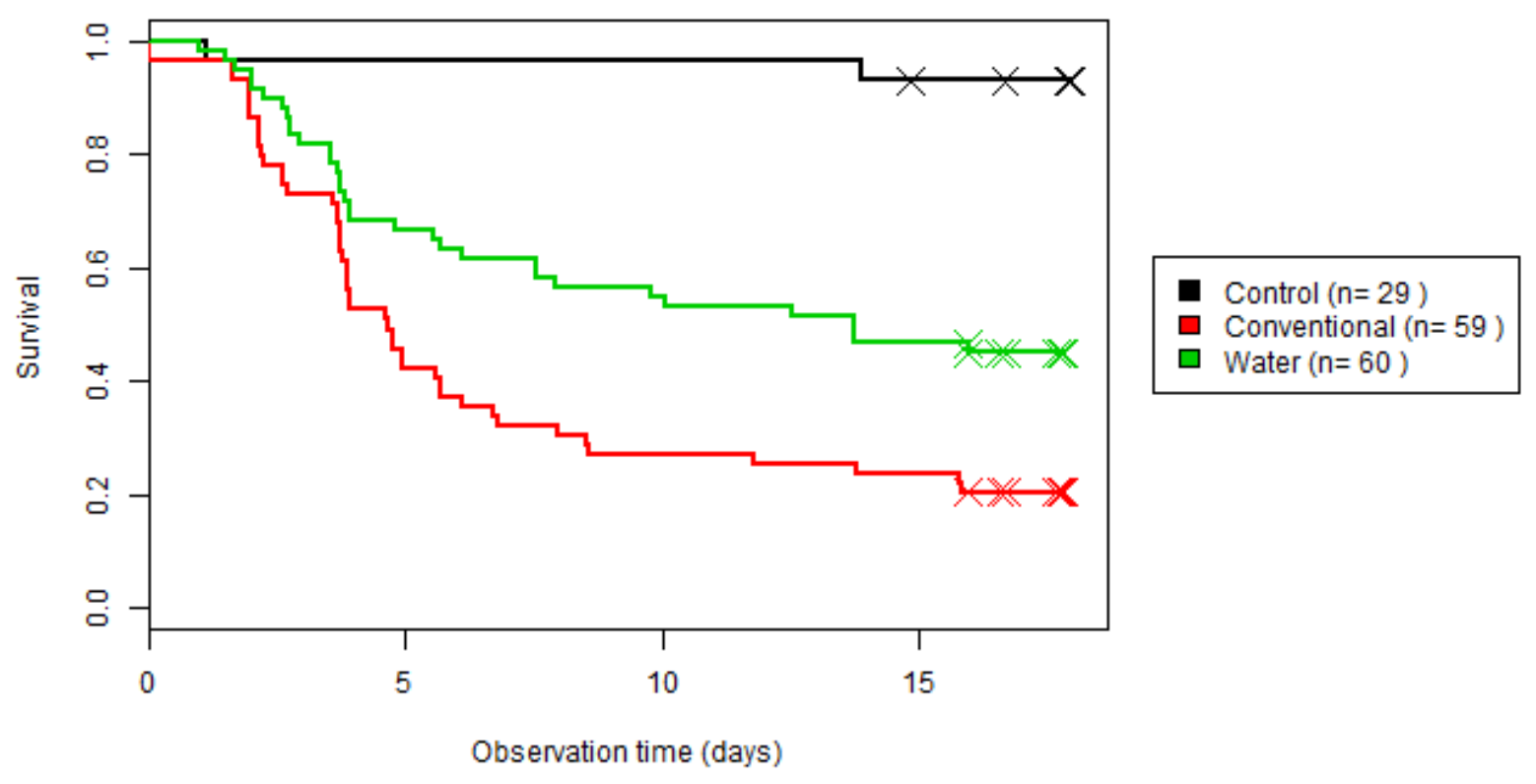


Wageningen Marine Research

T +31 (0)317480900

E: marine-research@wur.nl

www.wur.eu/marine-research

Visitors' address

- Ankerpark 271781 AG Den Helder

- Korringaweg 7, 4401 NT Yerseke

- Haringkade 1, 1976 CP IJ muiden
Wageningen Marine Research is the Netherlands research institute established to provide the scientific support that is essential for developing policies and innovation in respect of the marine environment, fishery activities, aquaculture and the maritime sector.

\section{Wageningen University \& Research:}

is specialised in the domain of healthy food and living environment.

\section{The Wageningen Marine Research vision}

'To explore the potential of marine nature to improve the quality of life'

\section{The Wageningen Marine Research mission}

- To conduct research with the aim of acquiring knowledge and offering advice on the sustainable management and use of marine and coastal areas.

- Wageningen Marine Research is an independent, leading scientific research institute

Wageningen Marine Research is part of the international knowledge organisation Wageningen UR (University \& Research centre). Within Wageningen UR, nine specialised research institutes of the Stichting Wageningen Research Foundation have joined forces with Wageningen University to help answer the most important questions in the domain of healthy food and living environment. 